\title{
WESTERN COMPLEXES OF HUNGARIAN CHURCHES OF THE EARLY XI. CENTURY
}

\section{BÉLA ZSOLT SZAKÁCS}

UDC: 726.033.4(439)

Original scientific paper

Manuscript received: 15. 10. 1996.

Revised manuscript accepted: 01. 04. 1997.
B. Zs. Szakács

Catholic University of Hungary Budapest-Piliscsaba

Hungary

The church organisation of Hungary under its first king, Saint Stephen (ruled between 997-1038), resulted in the building of the first monasteries (e.g. Pannonhalma), cathedrals (e.g. Kalocsa, Veszprém and Pécs) and provostships (e.g. Székesfehérvár). These churches mostly disappeared during the centuries, but their spatial organisation can be partly reconstructed. One of their common features is the complexity of the western parts. On the one hand, various architectural types can be found (western apse with crypt, transversal mass with towers, two-tower façade), but origins of an architectural tradition can also be detected. The main element of this tradition, complementary to former research, is not the westwork, but the presence of two western towers which will be a "leitmotiv" of the later Romanesque architecture in Hungary.

1996 is a year of continuous celebrations of various anniversaries in Hungary. First of all, the ancestors of the Hungarians arrived in the Carpathian basin 1100 years ago. The 1000-year celebration of the same event, the Millennium in 1896, is worthy of commemoration in itself. Nevertheless, the Benedictines celebrate their first thousand year presence in Hungary, in the monastery on Mount St Martin (called Pannonhalma since the 19th century). Prior to this, commemorated with an attractive exhibition accompanied by a three-volume catalogue,' the buildings of the monastery were restored. During the archaeological excavations, connected to this renovation, the remains of the first abbey church came to light - as the most precious praise in itself. This recovery threw new light on the western complexes of Hungarian churches of the early 11 th century. Therefore it is quite reasonable to overview the sacral architecture of this period from the perspective of the arrangements of the west end of the churches.

Since the Carolingian period western parts of the churches had been usually built in a complex form and were separated in a way from the rest of the building. In the Ottonian period new tendencies appeared. The Carolingian westwork lost its autonomous arrangement and was gradually integrated into the space of the church. Similarly, the usage of these rooms was transformed and the previous liturgical functions partly disappeared or survived in a modified form. New, less complicated types of arrangements appeared at the west end of the churches in the Ottonian period, preceding some of the standard types of Romanesque architecture, among them the two-tower façade.?

Remarkable debates appeared just in this respect in the last decades. Following Hans Reinhard, scholars reconstructed monuments, previously thought to have had two western towers, with a middle tower or a group of towers at the west. ${ }^{3}$ Nowadays these critics seem to be too rigorous and scholars tend to accept the traditional reconstruction. ${ }^{4}$ We are well in time to reconsider the significance of the East Central European region in the history of the twotower façade.
In this respect we have to re-evaluate Hungarian monuments modifying the earlier concepts which were based essentially on Carolingian prototypes. In the following overview we will reconsider which types of western complexes were characteristic of the Hungarian churches in the early 11 th century, in which sense were these common or divergent, and how their difference or similarity can be explained.

The monastery of Pannonhalma originated in the time of Duke Géza (died in 997). After his death, privileges were granted to the monastery in $1001 / 2$ by his son, the first Hungarian king, Saint Stephen (ruled between 997-1038). ${ }^{6}$ With this act he not only laid the foundation of the first Hungarian Benedictine monastery but started the great work organising the Latin Church in his country.

The greatest part of the present church at Pannonhalma is from the 13 th century (Fig. 1). ${ }^{7}$ The only exception, not to mention smaller additions of the 15th century, is the

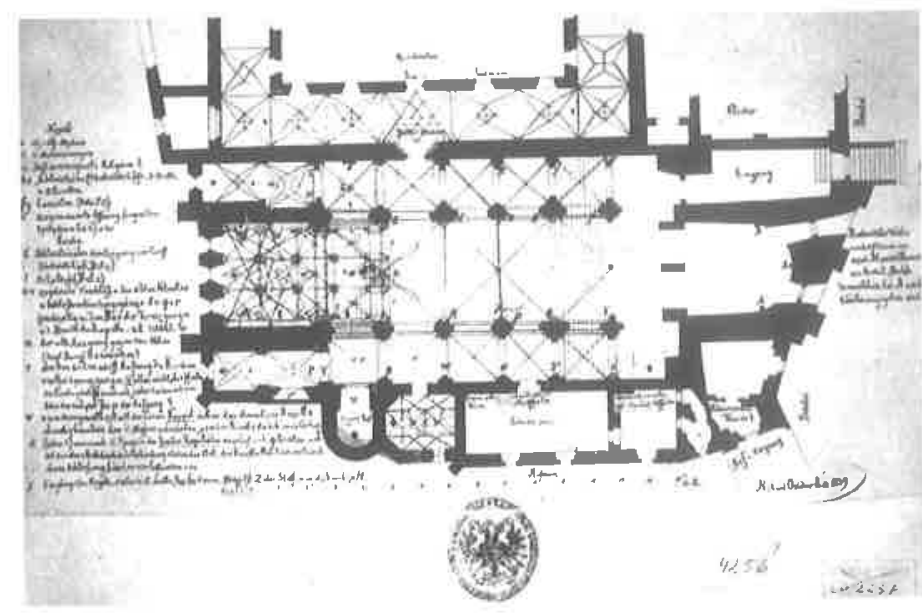

fig. 2. Pamonhalma, gronud plan of the abbey church by Robert Andorka, 1859 (indicating state before 1828) 


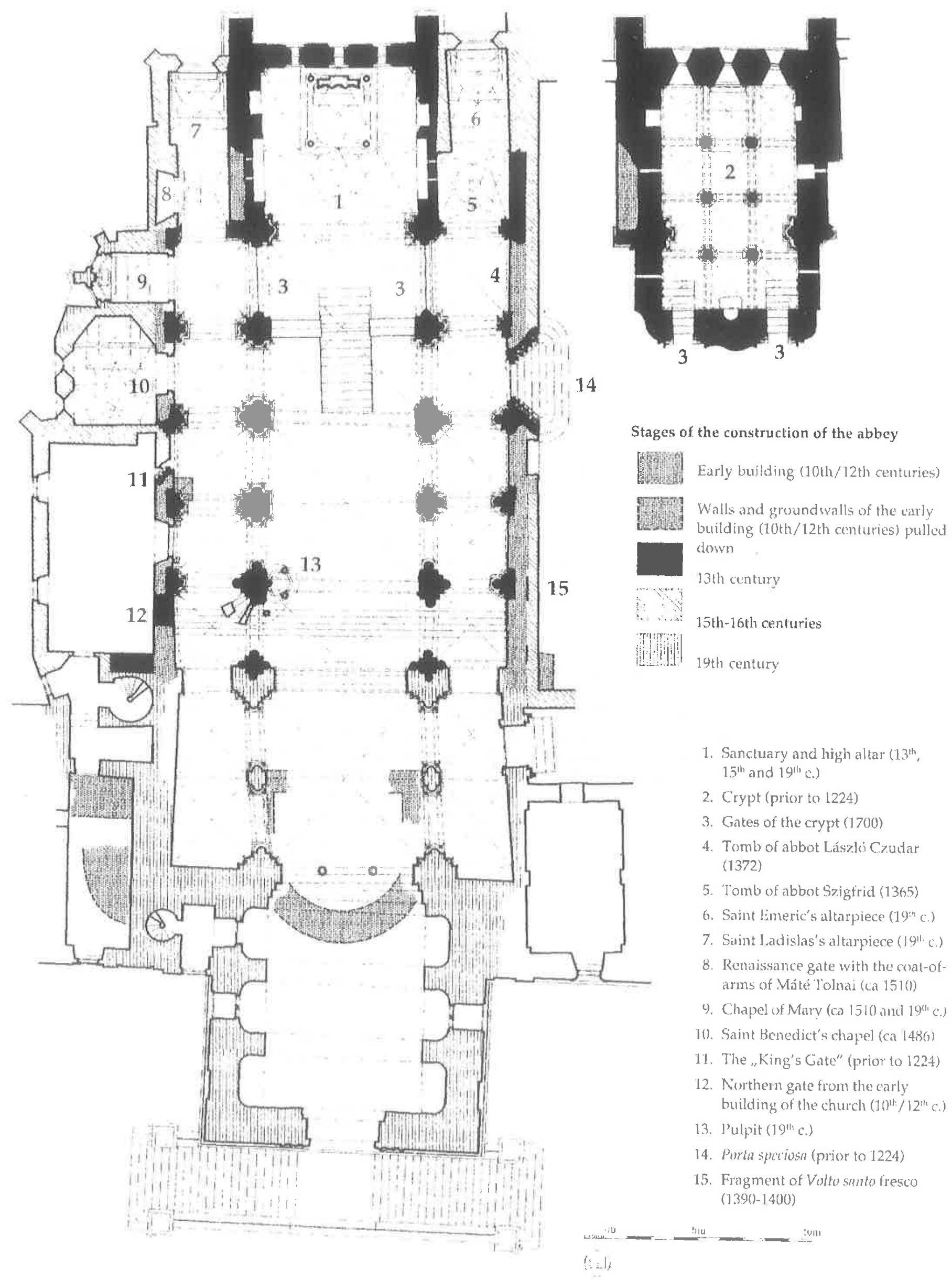

fig. 1. Pannonhalma, stages of the construction of the abbey church (by I. Takács indicacting the excavations of Cs. László) 


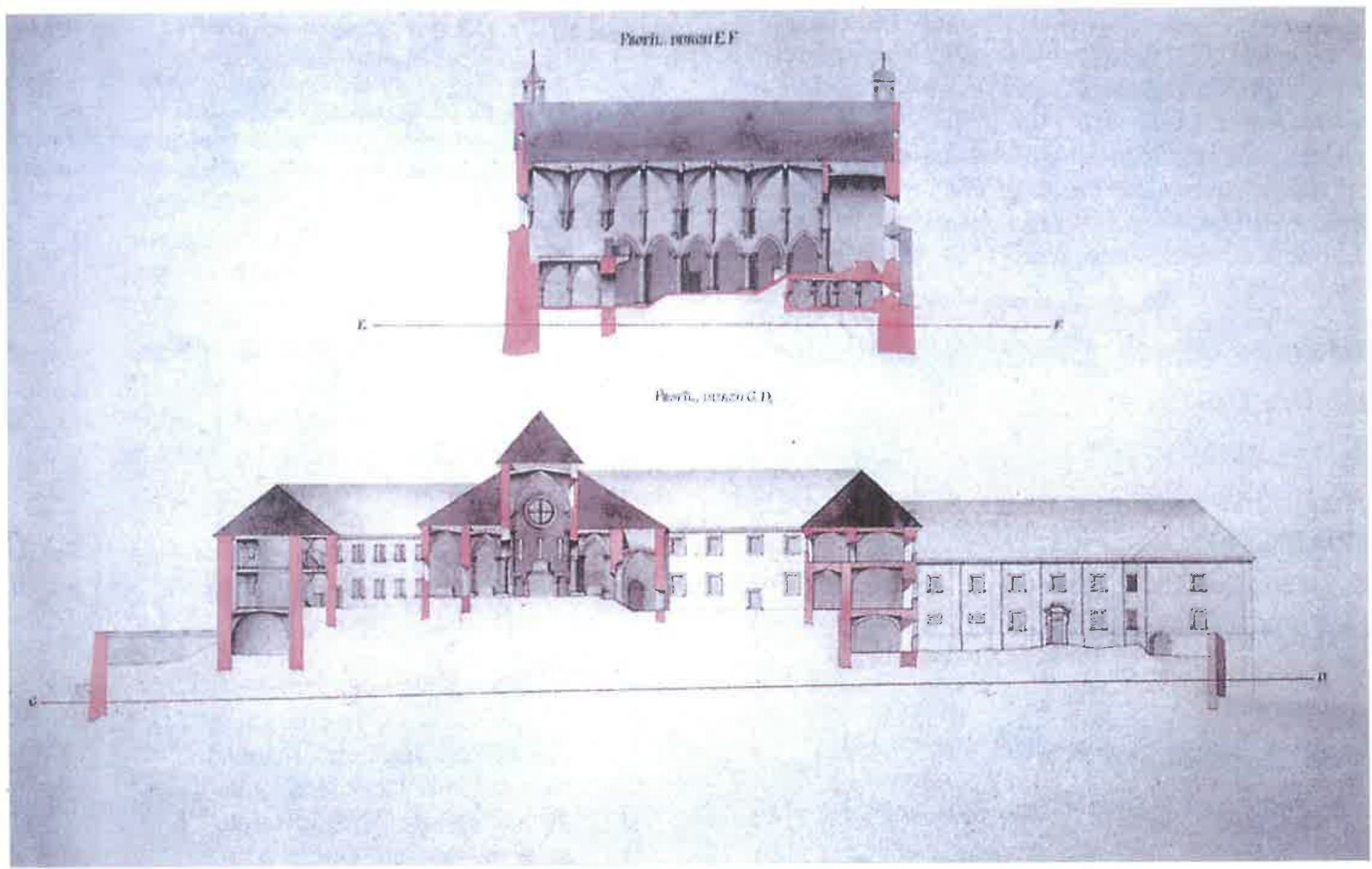

fig. 4. Pannonhalma, sections of the abbey church, 1787

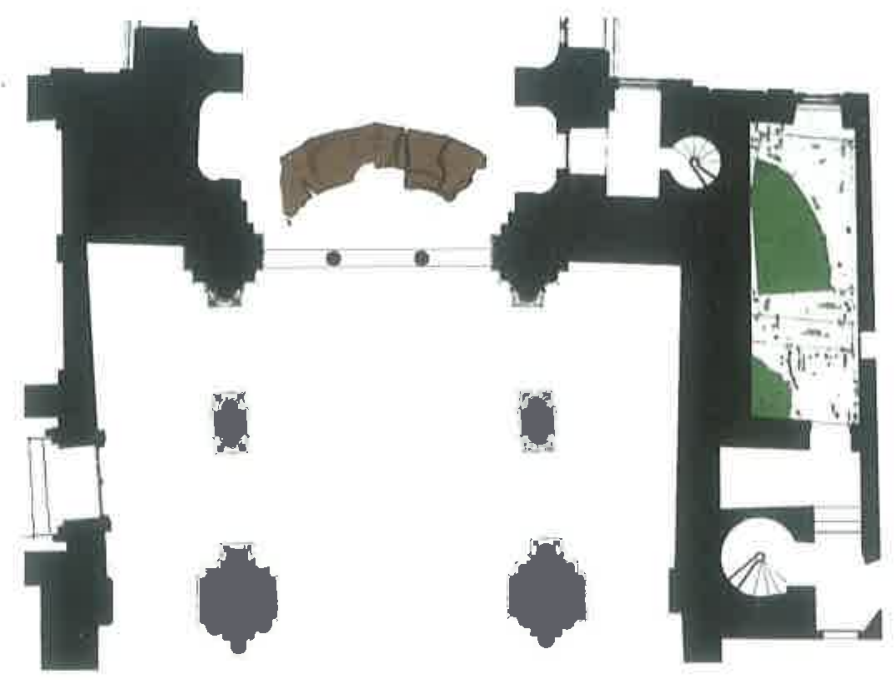

fig. 3. Pannonhalma, excavations at the westem part of the abbey church (brown: excanation of Cs. Lászlo, 1994; green: foundations found in 1995)

great western tower, built from 1828 in neo-classical style. "The previous state of this western part is known from some drawings of the 18 th and 19 th centuries (Fig. 2). ${ }^{10}$ These drawings served as a starting point for the hypothesis of Melinda Tóth that the first building did not disappear totally. In an article on the art and architecture in the time of Saint Stephen she realised that the great western apse, represented on these drawings, could not have been part of the building of the 13th century, but fits well to the early 11 th century. ${ }^{11}$

The recent archaeological excavation proved this hypothesis, finding the walls of a western apse under the present tower (Fig. 3). ${ }^{12}$ Its northern and southern parts were destroyed by the basements of the tower of the 19th century, but the central part survived together with the fragments of a window on the north and a niche on the south. The original terrazzo floor of the room is almost 2 meters under the present bottom surface. Thus it can be reconstructed as a crypt with a sanctuary above it. However, this original arrangement was changed in the 13th century, when the crypt was filled up to the same level of the nave and a new tribune was built over it. This phase is represented on a longitudinal section from 1787 (Fig. 4). ${ }^{13}$

In a room north of these parts another basement was found in the summer of $1995 . .^{14}$ Its north-west end forms a quarter of a circle and continues towards the east. Unfortunately, its relation to the apse is not clear; however, it is quite probable that it is a basement of a round tower. On the plan of the 19th century already mentioned (Fig. 5), ${ }^{15}$ there is an inscription just over this part with the words "Kleiner runder Thurm?" This can be the sign of the memory of a medieval turret, already demolished by the 19 th century. Moreover, there are representations of the monastery from the 18 th century showing it with towers. ${ }^{16}$ One of these towers could be connected to the roundshaped basements.

What is more, the wall of the south aisle, earlier than the 13th century, seems to turn originally to the south not far from the apse. Opposite to it, the wall of the north aisle 


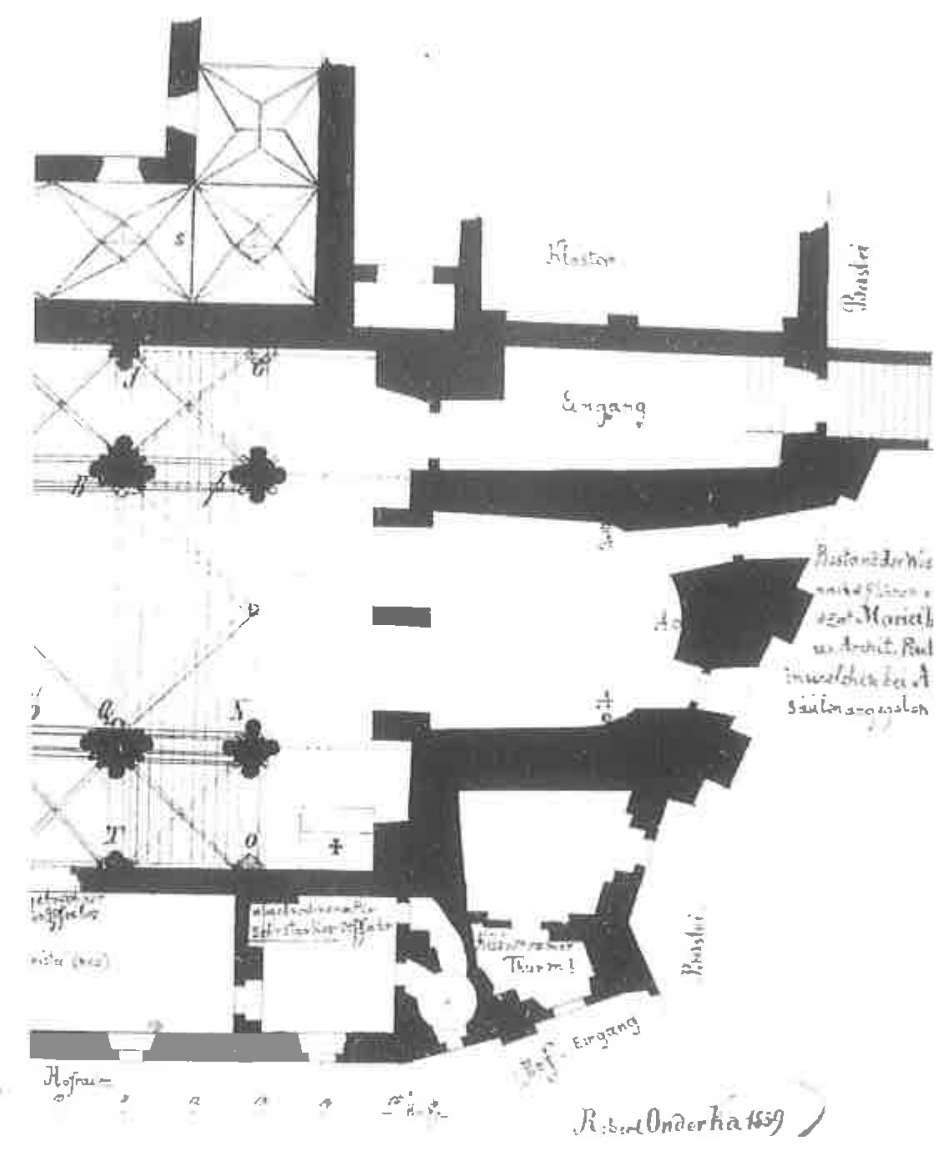

fig. 5. Pannonhalma, detail of fig. 2.

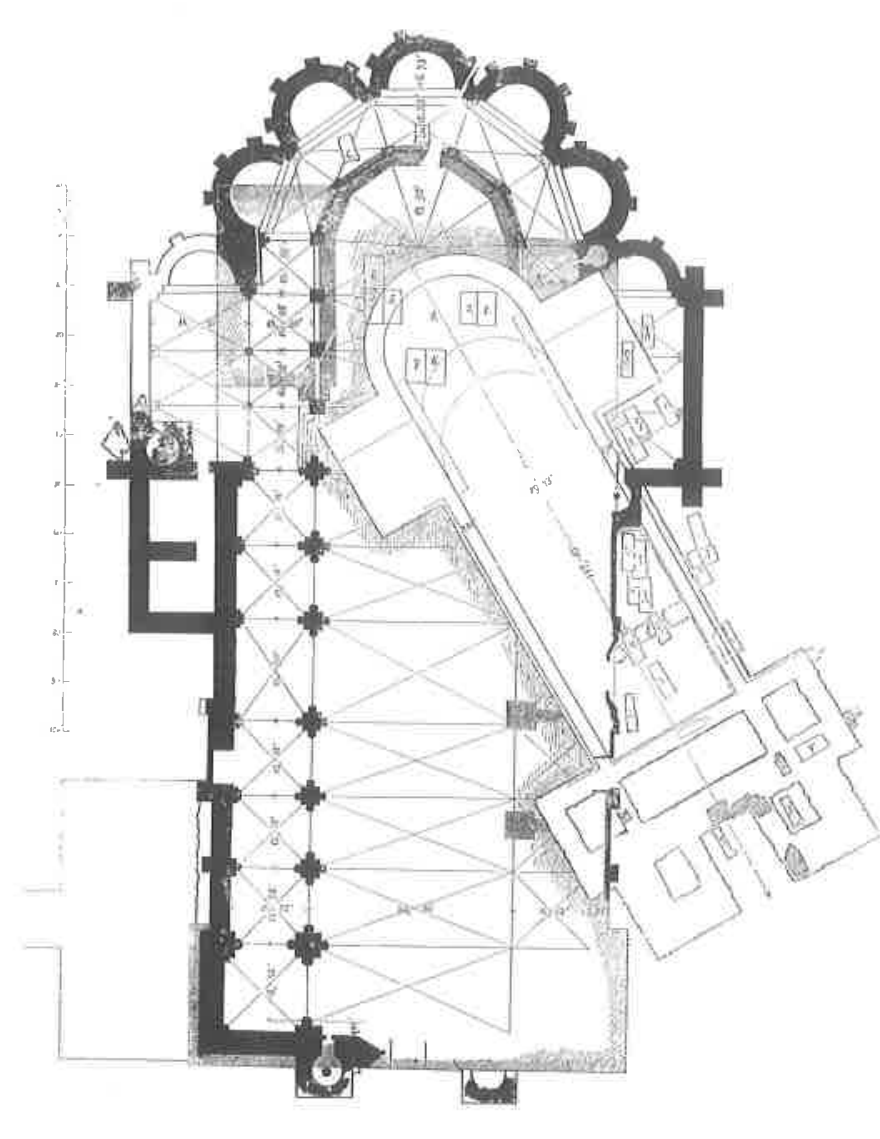

fig. 6. Kalocsa, excavations of I. Henszlmann, 1869 has a large buttress. The buttress can be dated to the 13th century but it probably replaced another earlier structure. Consequently, the church seems to be wider in its original form at the western part. It can be described as a western transept or an enlargement for tribunes. This part was connected to the western apse with crypt and a pair of round towers.

The western apse with crypt and transept appears quite frequently in the Ottonian period. ${ }^{17}$ One of its well-known example is the cathedral of Bamberg, ${ }^{18}$ founded by emperor Henry II, brother-in-law of king Stephen the Saint. We know that the Hungarian archbishop Anastas/Astrik took part in the synod of the foundation of the bishopric (1007) as well as on the consecration of the cathedral (1012). ${ }^{19}$ The original western apse of the cathedral of Worms, ${ }^{20}$ dated between 1000 and 1018, was connected to two round towers. An earlier example, the second building of the Abdinghofkirche at Paderborn ${ }^{21}$ from c. 850 already unified the transept, apse and round towers at the west. A similar arrangement with a crypt but with rectangular towers can be found at the St Stephen church at Würzburg, ${ }^{22}$ dated to the first third of the 11th century. In fact, the best parallel I have found is the cathedral of Merseburg, ${ }^{23}$ where the apse with a crypt, transept and round towers are together from the first half of the 11th century, although at the east end of the church.

Though this arrangement is well-known in Western Europe, it is extremely rare in Hungarian architecture. ${ }^{24} \mathrm{On}$ the other hand, we have to realise that the architecture of the time of King Stephen is very poorly known. The other monasteries founded by the king, as Bakonybél, Zobor, Pécsvárad and Zalavár, have mostly disappeared, and the arrangement of the western parts of their buildings cannot be reconstructed. ${ }^{25}$

On the other hand, in organising the Christian church the first Hungarian king founded not only monasteries but bishoprics too. According to the tradition, the ecclesiastical system with two archbishops and eight suffraganeus bishops was fully developed by the end of his rule. ${ }^{26}$ Some of the cathedrals of this early system can be partly reconstructed. In the following, I will present the cathedrals of Kalocsa, Veszprém and Pécs, and finally turn to the provostship of Székesfehérvár, the favourite foundation of the king.

Unfortunately we have no information how the first cathedral of Esztergom, the seat of the leader of the Hungarian Church looked like. ${ }^{27}$ On the other hand, the cathedral of the other archbishopric, Kalocsa is better known.

The present cathedral is Baroque in style but stands on the basements of a building of the early 13th century. Its arrangement with transept, ambulatory and apsidiols, widespread in the West, is unique in Hungary. However, the building of the 13th century was preceded by another one, different in type and orientation. Its arrangement is known mainly from the excavations of Imre Henszlmann in the 19th century. ${ }^{28}$ As it is indicated on his plan (Fig. 6), he found massive foundations of towers on the western parts of the church. On the east, according to his description, "die Reste des südöstlichen Thurmes sind in grösseren Höhe erhalten". ${ }^{29}$ We do not know exactly, what Henszlmann found there, however, this was fundamental for his theory on the early Hungarian cathedrals reconstructed with four towers. This theory was later refused by Erno" 


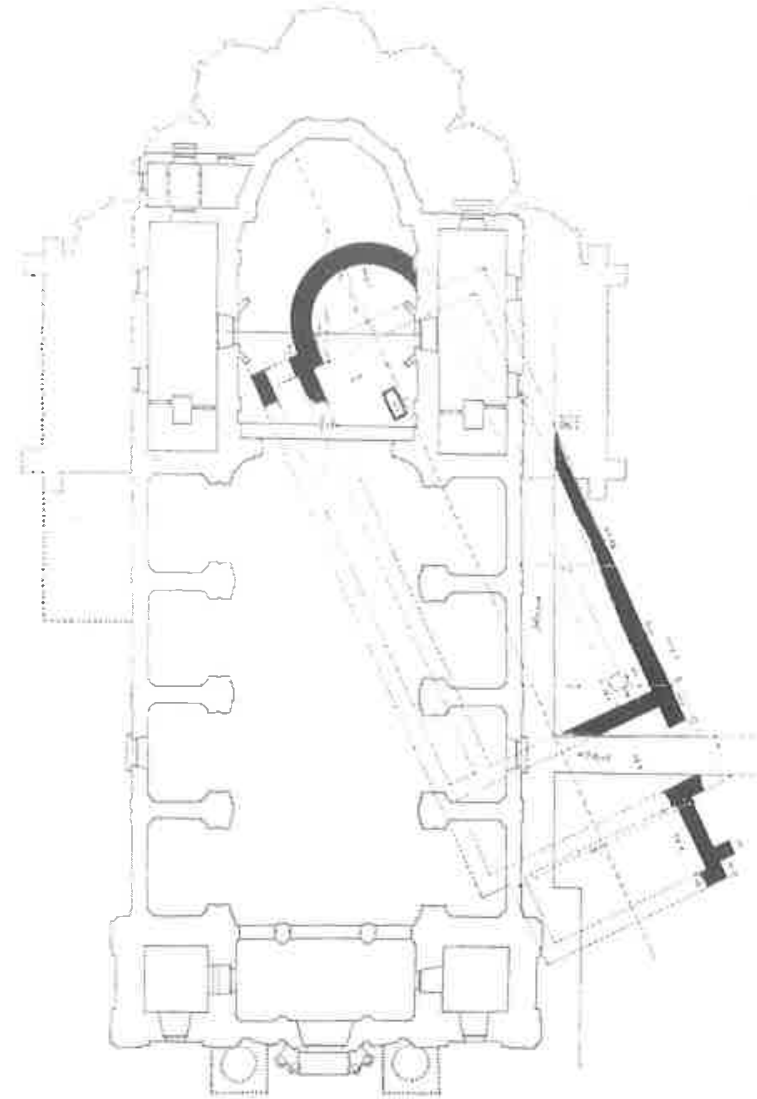

fig. 7. Kalocsa, excavations of E. Foerk, 1910-11
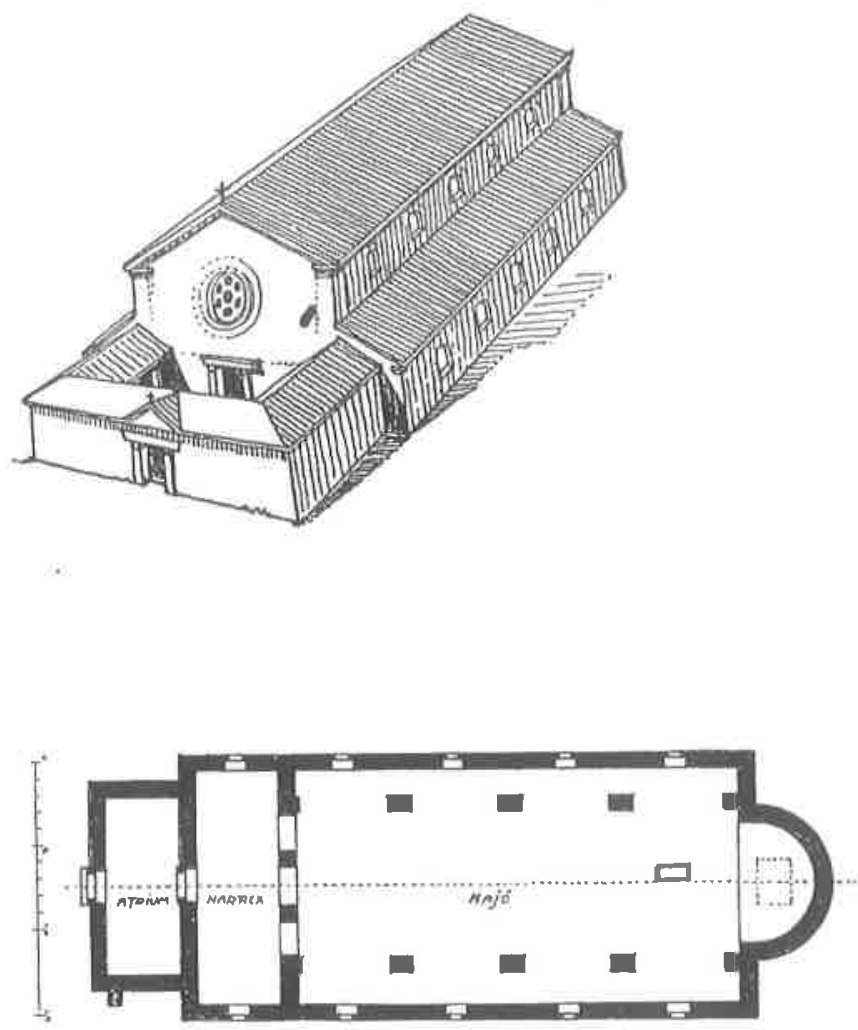

fig. 8. Kalocsa, reconstruction of the cathedral by E.Foerk, 1912
Foerk, who led the restoration of the cathedral between 1907-12. ${ }^{30}$ In 1910-11 he excavated the remains of the apse of the early cathedral in the sanctuary of the present church (Fig. 7). Contrary to Henszlmann's hypothesis, he did not find remains of eastern towers, what is more, he explained the western foundations as the walls of an atrium and a narthex (Fig. 8).

It is clear that Foerk's reconstruction of the first cathedral as a paleo-Christian basilica cannot be accepted and, at least for the western parts, we should return to Henszlmann's concept. The large foundations seem to be of towers, and because their inner walls are less strong, this complex can be reconstructed as a transversal mass with two towers. The basements east of this structure can be later, as it was noticed during a short excavation more recently, ${ }^{31}$ or, if they are from the same period, they belonged to rooms with tribunes ${ }^{32}$ Anyhow, it seems to be a complicated structure with towers and tribunes. The next wall towards the east can mark the border of this part, and the fact that this foundation was broken by two tombs not later then the 12th century, can demonstrate how the western complex was gradually integrated into the space of the church.

The presence of towers at the west can be assumed in another cathedral too. The bishopric of Veszprém is considered to be the earliest one in Hungary. According to the sources, the cathedral was founded and donated by Gisella, wife of King Stephen. ${ }^{33}$ The cathedral was associated with the Hungarian queens during the whole Middle Ages - it was used for their coronation and there was here a sedes reginalis. ${ }^{34}$ Thus its significance is parallel in a way with that of Székesfehérvár, to be described later, and these ques-

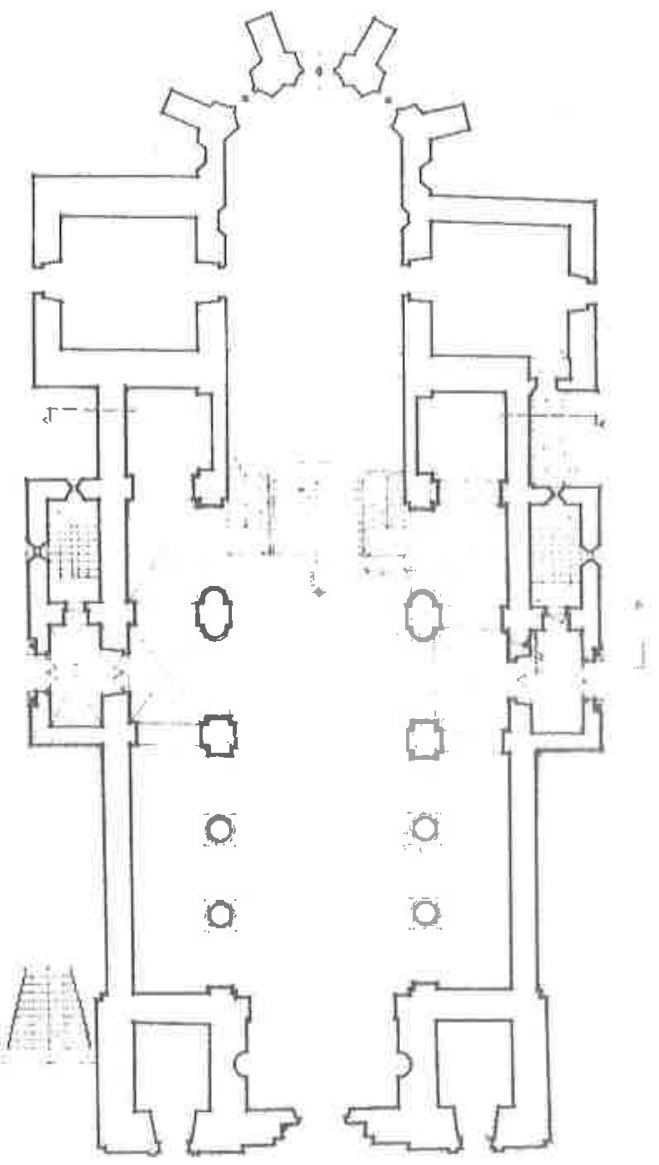

fig. 11. Veszprém, ground plan of the cathedral by F. Erdei, 1974 


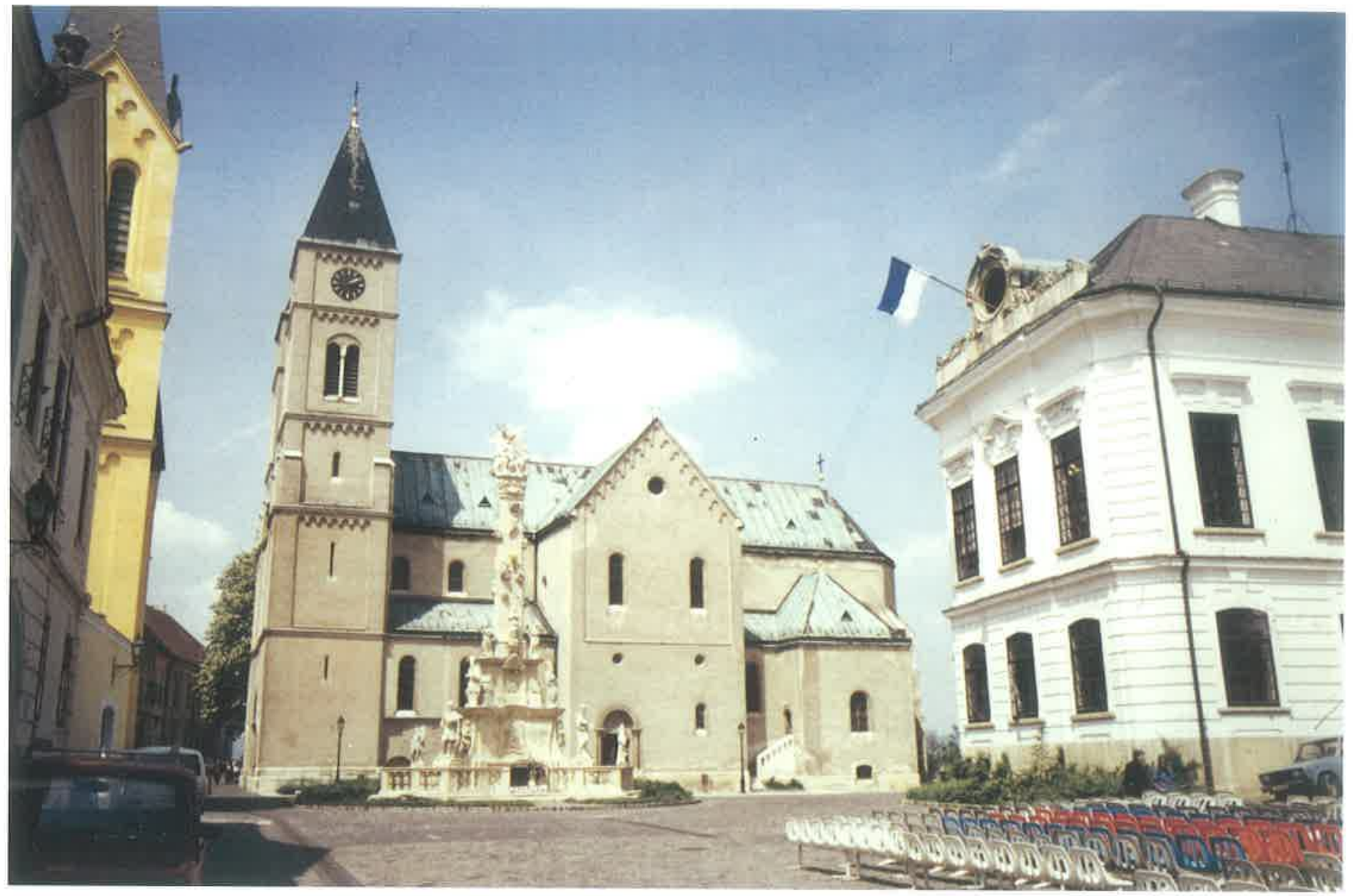

fig. 9. Veszprém, south façade of the cathedral (photo: author)

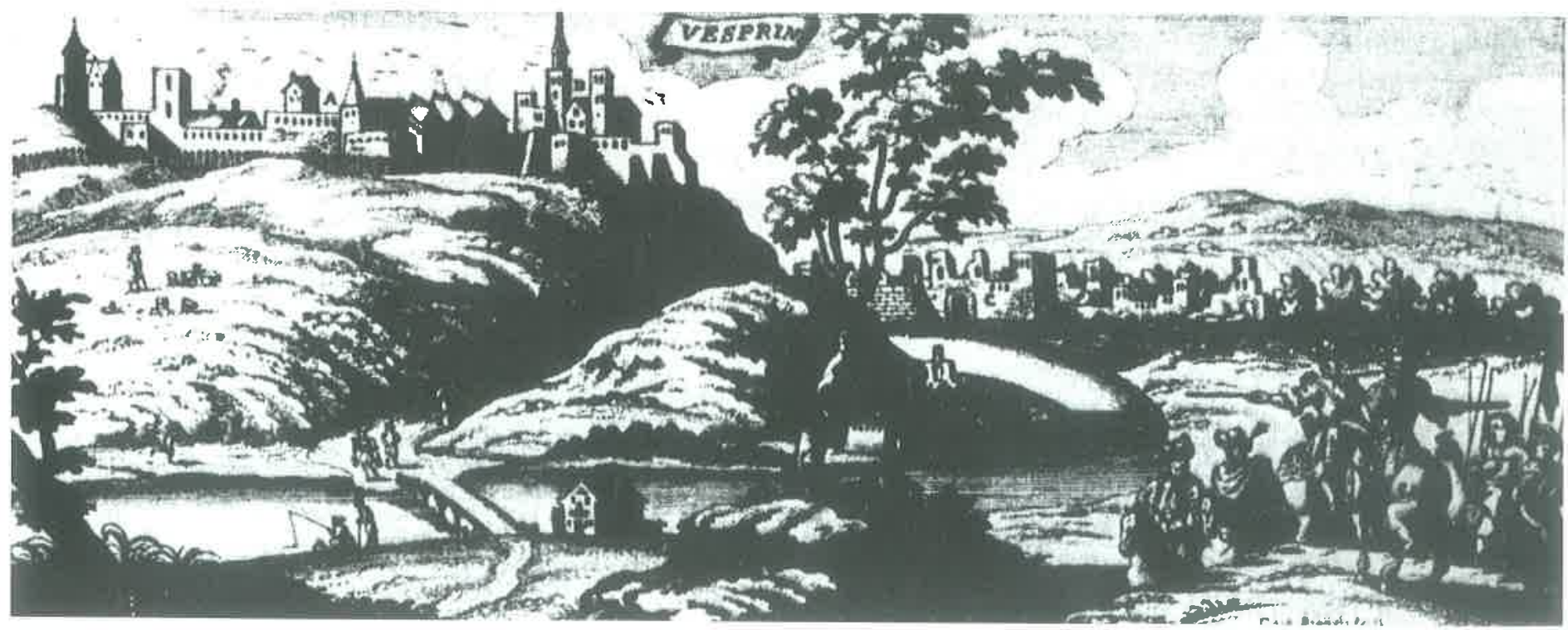

fig. 12. Veszprém, engraving of Caspare Bouttats, 1684

tions are perhaps not independent from the arrangement of the western complex of the building.

The Romanesque façade of the present church is the result of the restoration of 1907-10 (Fig. 9). ${ }^{35}$ Previously it was Baroque in style, rebuilt in 1723 , but preserving the walls of the medieval cathedral (Fig. 10). ${ }^{36}$ Its sanctuary, with the crypt, belongs to the period of 1400 , but a considerable part of the building is from the 11 th century. Some carvings related to the style became widespread in Hun- gary in the second third of the 11th century and can date the building ${ }^{37}$ (The closest parallel is from the nearby monastery of Tihany, founded by king Andrew I in 1055 $5^{38}$ ). The church was built with a nave and two aisles but the two central bays have two extra aisles. Above these extensions and the western bays of the aisles there were tribunes (Fig. 11).

The medieval arrangement of the western parts is not exactly known but the core of the western complex is from the early church. The examinations led by Sándor Tóth in 


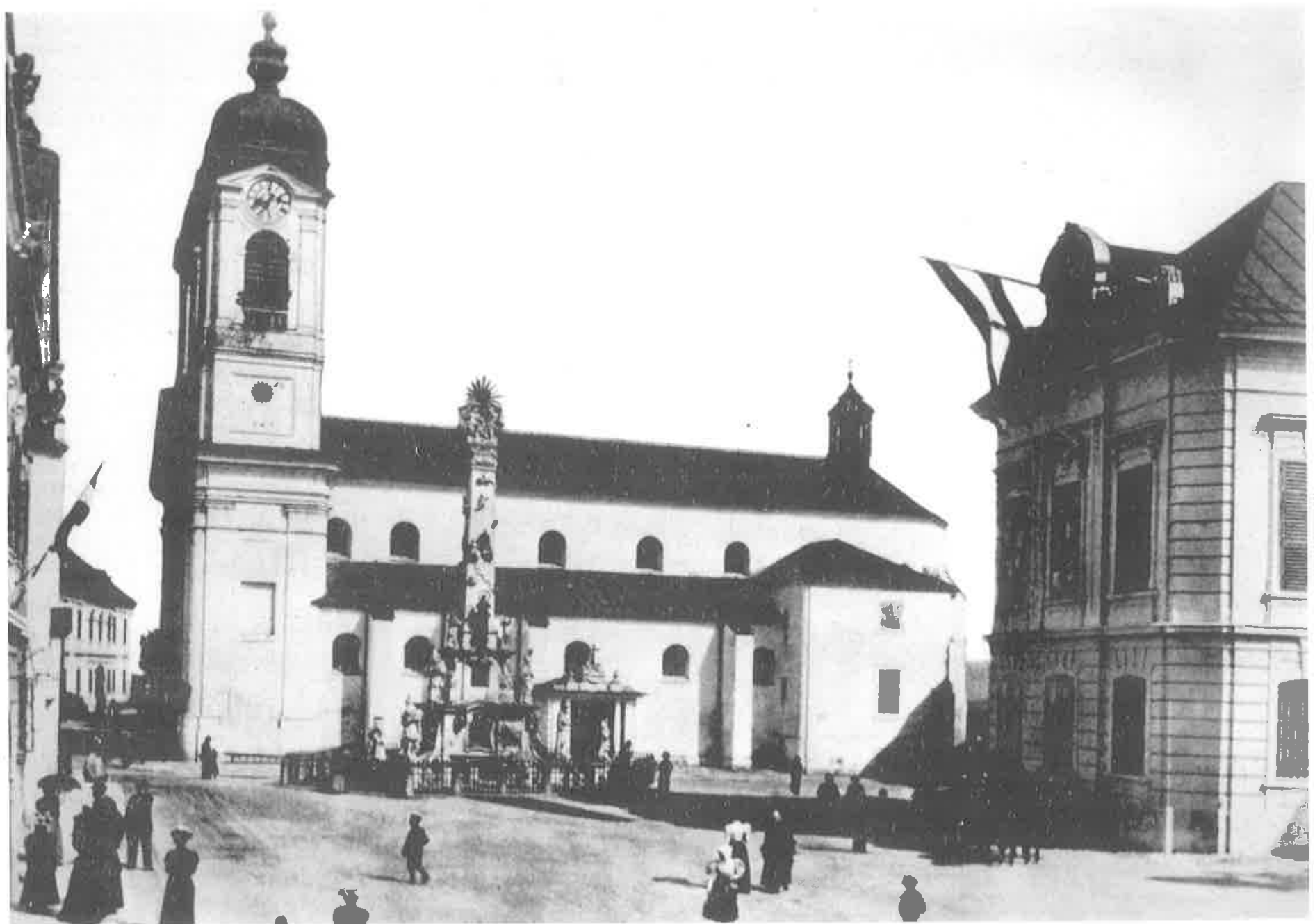

fig. 10. Veszprém, south façade of the cathedral (photo: Mór Erdélyi, c $1900)$

1968-73, demonstrated that the ground floor of the north tower was originally closed to the east, west, and north, but open to the south. It had a barrel vault which was redone twice in the Middle Ages. The south tower, where a Baroque staircase can be found, may have looked identical. The wall of this tower proved to be medieval above the tribune level.

The continuous presence of western towers of the building is proved by representations of the 16-17th century (Fig. 12). ${ }^{34}$ They could be dated to the Gothic rebuilding of the church c. 1400 . However, the redone barrel vaulting in the north tower points to the Romanesque period. So the western towers seem to belong to the Romanesque phase and it is also possible that this arrangement goes back to the first cathedral.

Even less known is the early phase of the cathedral of Pécs. The present church dates from the restoration of 1882-91 when it was totally rebuilt in neo-Romanesque style (Fig. 13). However, the main structure is from the 12th century. The three-aisled, basilical church has three apses at the east, a large crypt and four towers, two at each end of the building added to the last bays of the aisles on the north and the south side (Fig. 14). ${ }^{40}$

The only source how the Romanesque western façade of the cathedral looked like is a drawing of Mark Weinmann from the end of the 18th century (Fig. 15). It is strange that on the ground floor the walls of the towers form a homogeneous mass with the façade of the aisles. The decoration

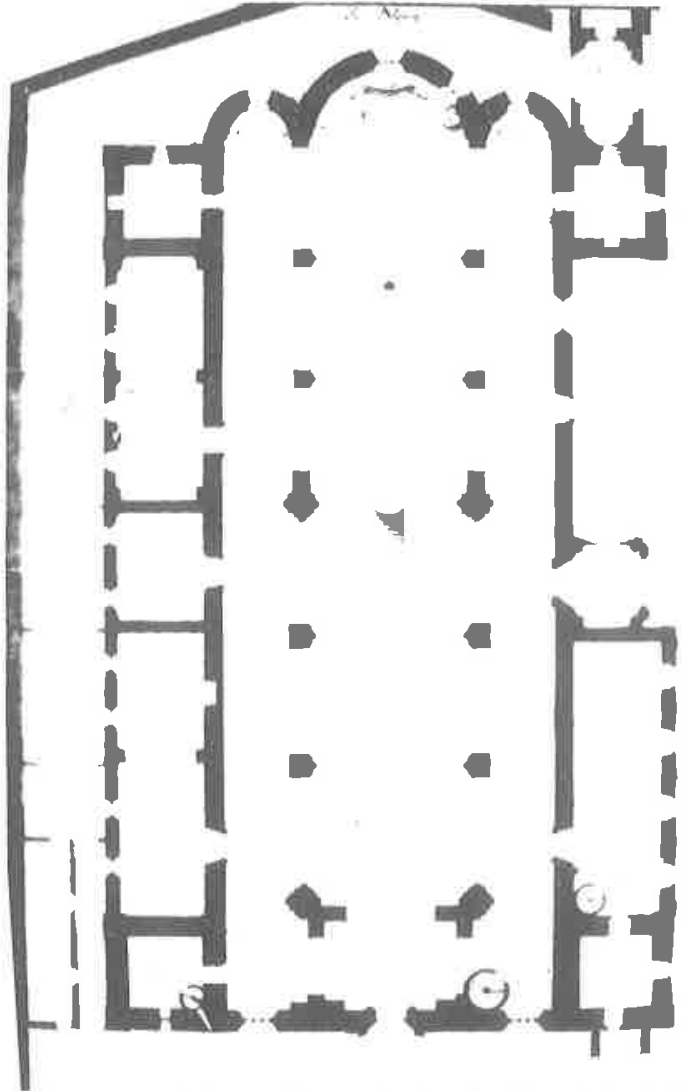

fig. 14. Pécs, ground plan of the cathedral by Jozsef Buck, 1805 


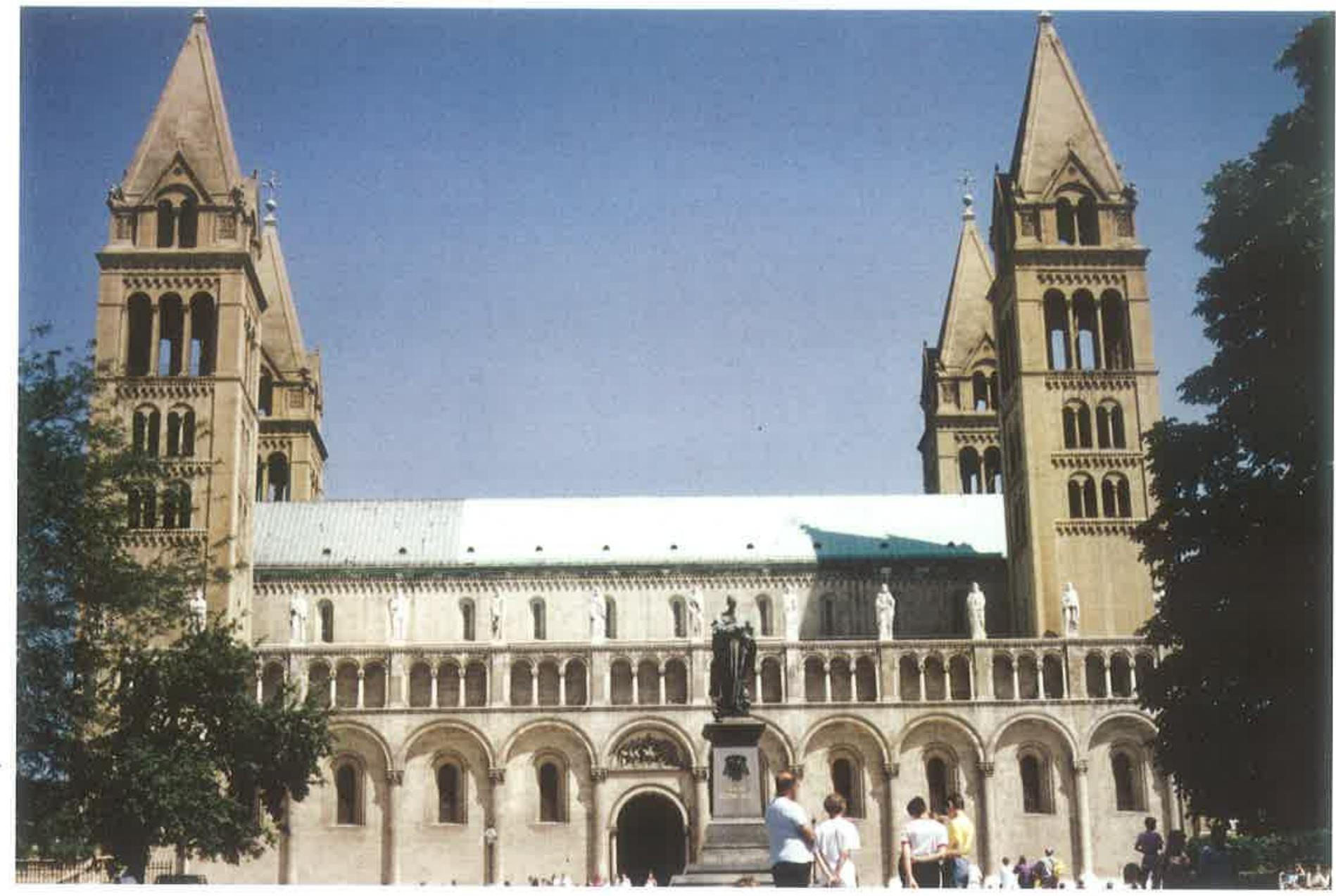

fig. 13. Pécs, south façade of the cathedral (photo: author)

of the upper floors is probably from the 12-13th century. In the upper part of the façade five round-shaped windows are represented, in contradiction with the basilical arrangement of the 12th century. According to Melinda Tóth's hypothesis, these parts may be the remains of a transversal western complex of the earlier cathedral. The arches visible in the walls of the façade can be traces of the former connection between the building and a Paleo-Christian mausoleum in the vicinity, the so-called Cella Trichora. This mausoleum of the 4th century was still in use in the 11-12th century. ${ }^{41}$ It is quite possible that this building served as a sacral centre for the western complex of Pécs cathedral. And it is also significant that a large tribune was planned for the western part of the rebuilt cathedral of the 12th13th century, following somehow the earlier structure.

Although King Stephen established ten cathedrals, his favourite foundation was the provostship at Székesfehérvár. ${ }^{42}$ The provostship, dedicated to the Virgin Mary, was donated by the king after his victories over a Hungarian duke, Gyula (1003) and the Bulgarians (1018). It served as a royal chapel, ${ }^{43}$ being exempt from the jurisdiction of the bishop and after 1181 from that of the archbishop. The royal crown and the most important relics and treasures of the kingdom were kept here. Until 1527 almost all the Hungarian kings were crowned in this church, and a great number of them were buried here. Originally, it was planned as the burial place of the founder, King Stephen. His son, Emericus, died earlier than his father. Both were sepulchred in this church and their relics were venerated by pilgrims after their canonisation in 1083. The church was consecrated only when the king died in 1038. Still, the donation of a chasuble in 1031 (later used as coronation mantle $)^{44}$ and the burial of prince Emericus here in the same year suggest that some parts of it were already usable. Some of the mentioned functions could have been in connection with the church's western complex. ${ }^{45}$

After 145 years of Turkish occupation and various sieges, the materials of the ruined church were reused for building the Episcopal palace in the early 19 th century. A few decades later, in 1848, the first excavation has started. On the western parts there were archaeological campaigns in 1862 and 1882, in 1936, between 1969-71 and after 1988 until 1993. Recently the excavation is still in process, led by Piroska Biczó. Although the results were not yet published, we have some starting points for the reconstruction. ${ }^{46}$

The church was a three-aisled basilica with a huge apse and two chamber-like rooms on both sides at the east. The church was vaulted in the 14th century and enlarged with a great late Gothic sanctuary. The western parts, however, are less certain.

First of all, the remains of a large tower on the western part of the basilica were uncovered by Henszlmann (Fig. 16). This huge building is Gothic in style, but it is not the first one on this site. Under this tower the remains of an earlier structure were detected (Fig. 17). Similarly, some basements of a rectangular building, probably a tower were found at the western end of the north aisle. Therefore the basic elements at the west of the early church seem to be a pair of towers. Now the question is, how did the middle 


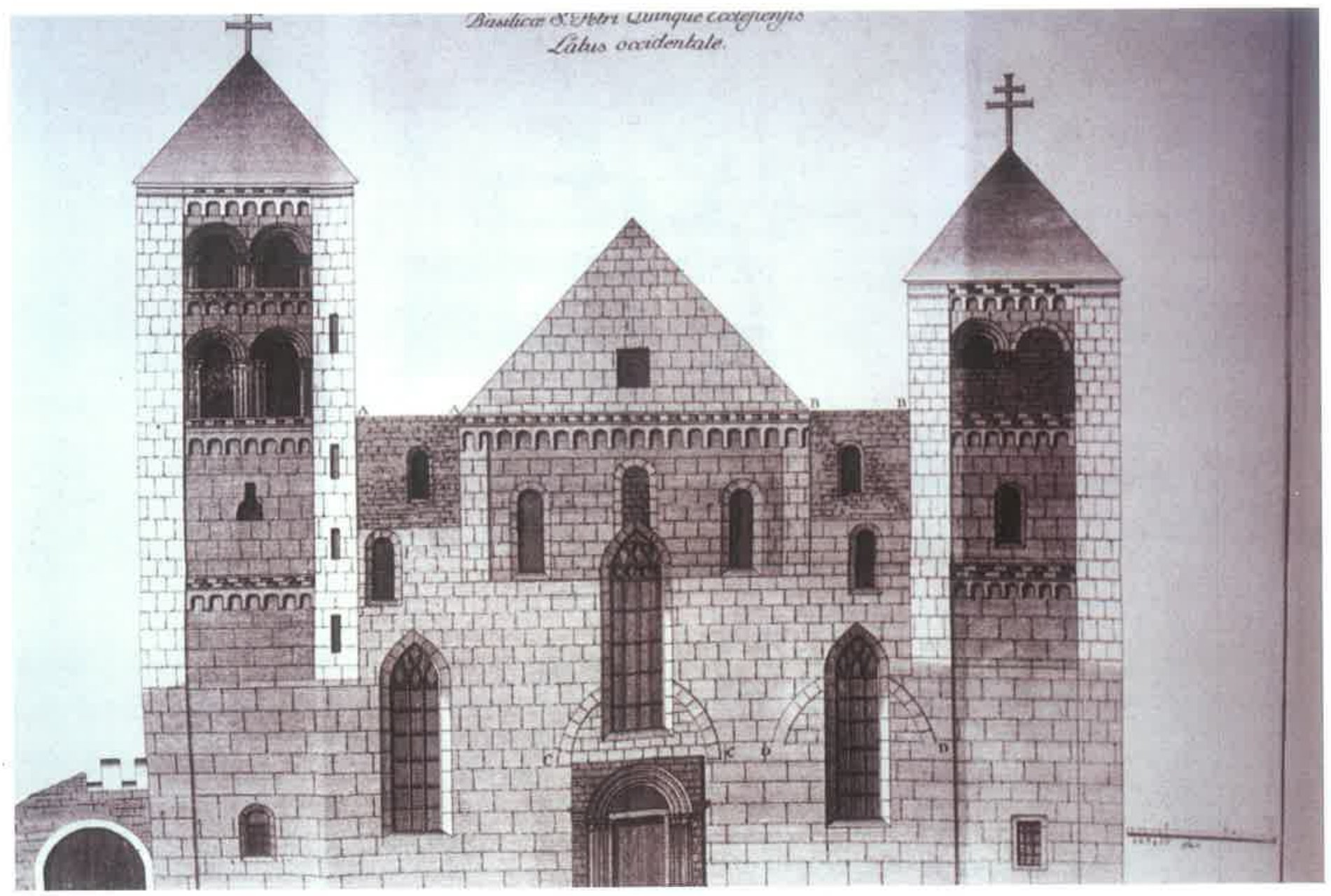

fig. 15. Pécs, western façade of the cathedral, engraving of Mark Weinmann, 18th century

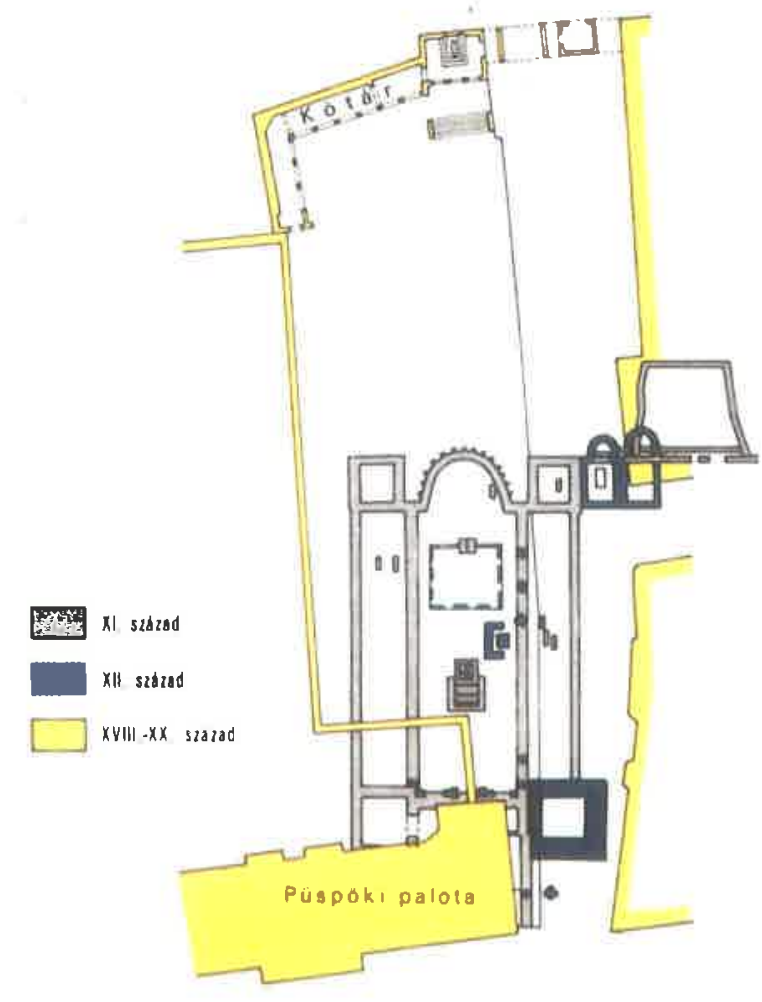

fig. 17. Székesfehérvár, excavations of A. Kralovánszky, 1988 part between the towers look. Kralovánszky found remains of piers in the nave, so the room between the towers and the nave were divided by arches. Unfortunately the south wing of the Episcopal palace is situated over the most important rooms. Nevertheless, basements of a four-lobed pier and a column, lying west of the south tower, suggested reconstructing the whole structure as a westwork of that type which is arranged with several pillars on the ground floor (Vollwestwerk). ${ }^{47}$ However, this type is characteristic rather for the Carolingian period and we could hardly find parallels for it in the Ottonian era. ${ }^{48}$ The basements of the pillars do not prove such a reconstruction either. The foundation of the four-lobed south pier is quite week, and therefore it may have not supported complex structures. What is more, this room was opened by arches on the south and west, so it can be described as a kind of entrance hall rather than the ground floor of a westwork. There are also arguments to consider this part a somewhat later addition.

So it is quite probable that the original structure was a kind of two-tower façade. In fact, the drawings from the 16-18th century represent the church almost consequently with two towers (Fig. 18). ${ }^{49}$ Although the realistic values of these prints are questionable, at least the number of the towers is perhaps acceptable.

As we have seen, the churches founded and built by King Stephen in the early 11 th century represent various types of western complexes. At Pannonhalma the western apse with crypt and a transept or tribunes, at Pécs a transversal mass, at Székesfehérvár, Kalocsa, and perhaps Veszprém a 


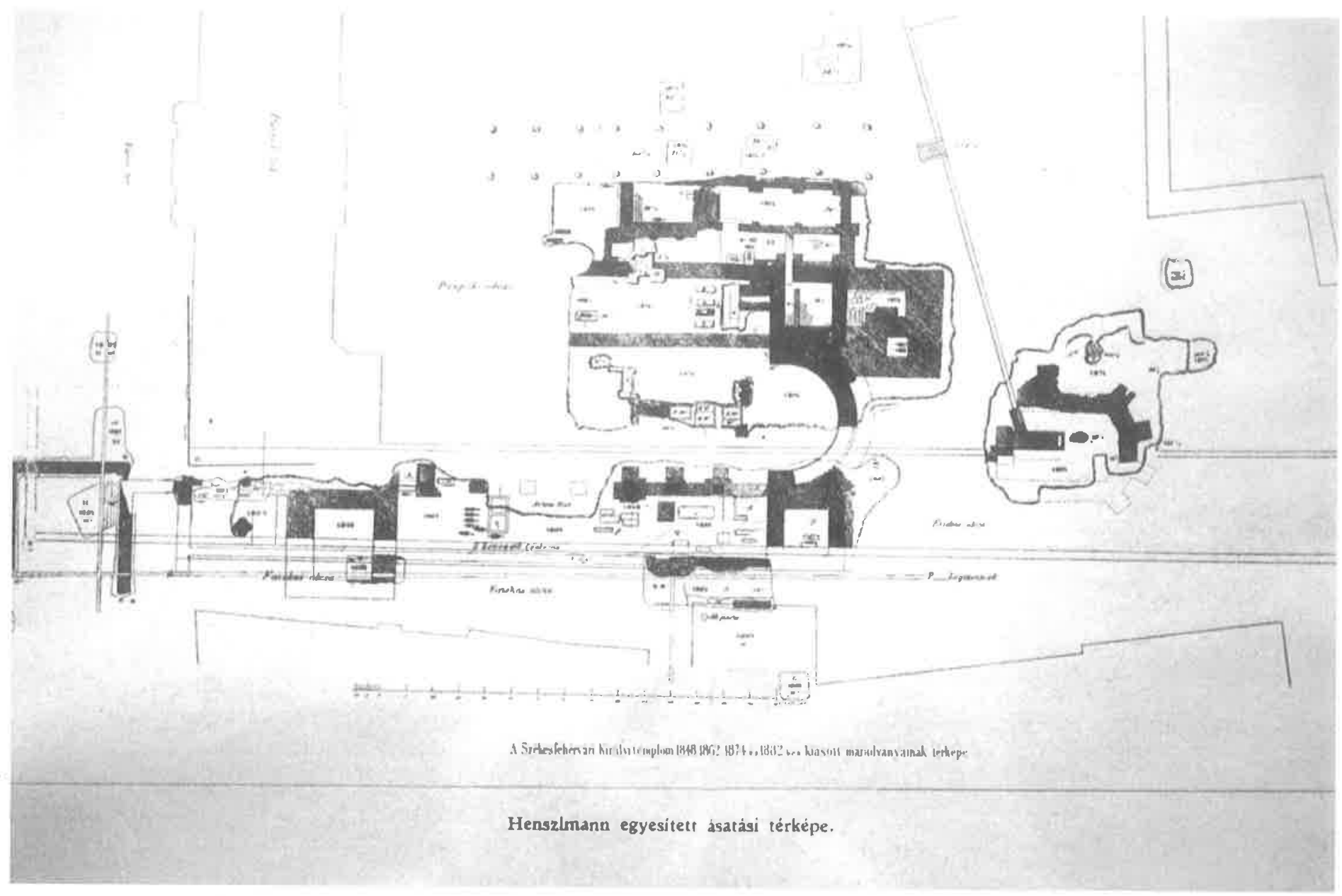

fig. 16. Székesfehérvár, excavations of I. Henszlmann between $1862-1882$

kind of two-tower façade can be reconstructed. The variety of these architectural solutions is not surprising, considering the different sources of the early Hungarian Christianity. ${ }^{50}$ Not to mention the Byzantine influences, monks and missionaries came mainly from German monasteries and bishoprics. According to the tradition, St Wolfgang made the first efforts to christianise Hungarians. Wolfgang, educated in the Reichenau and Würzburg, lived as a monk in Einsideln. After his attempt to convert Hungarians he became bishop of Regensburg (972-994). ${ }^{5 t}$ Another, more successful missionary was bishop Bruno, coming from St Gallen. ${ }^{52}$ The missionary work was partly coordinated by bishop Pilgrim of Passau (970-991). ${ }^{53}$ Although the influence of St Adalbert, bishop of Prague is perhaps less important, the activity of his associates as Radla, archbishop of Esztergom seems to be essential; this group mediated the influence of Magdeburg and Mainz. ${ }^{54}$ It is evident that priests arrived together with Gisella from Regensburg to the Hungarian court. ${ }^{55}$ Arnoldus of Regensburg came to Esztergom around 1028 where he propagated the liturgy of St Emmeram. ${ }^{56}$ These sporadic facts are not enough to reconstruct the whole palette of the sources of the early Hungarian Christianity, nevertheless, they can signify the main trends. Thus we have to count the influences of Suabia, Salzburg-Passau, Mainz-Magdeburg and Regensburg. ${ }^{57}$

These connections could inspire not only the liturgy of the young Hungarian church but its church architecture as well. However, within the variety of the enumerated monuments a special feature seems to return consequently, namely the western towers. This type of arrangement is known from the Upper Rhine region. It is problematic, whether the first cathedral of Strassburg was built with a two-tower façade by Bishop Werner between 1015-28, or whether it can be reconstructed with one tower over the central portion of the façade and two staircase turrets built onto the eastern corners of the central tower, identically with the present state of St Thomas at Strassburg. In fact, the ground plan is closer to the two-tower façade. ${ }^{58}$

However, there is a monument built with two western towers and it was ecclesiastically related to Strassburg. That is the St Leodegar church at Schönenwerd. ${ }^{59}$ Bishop Remigius of Strassburg gave it to the chapter of Strassburg cathedral in 778 and a provostship came into existence here after 800 . The present church can be dated to the second quarter of the 11 th century. On the western part of the building there were two towers built over a transversal mass (Querbau). Between the towers there was an open entrance hall on the ground floor. The core of the structure was a chapel on the first floor, wide as the whole church and open to the nave.

The nearby Benedictine abbey of Muri ${ }^{60}$ was founded by Radbot, ancestor of the Hapspurgs, together with the above mentioned Werner of Strassburg. The church can be dated between 1032 and 1064, and was rebuilt several times. On the western side there is a pair of towers. Although the northern one is Gothic above the tribune level, the southern tower is a Romanesque construction up to its $21.5 \mathrm{~m}$ height. So the western part can probably be reconstructed with two towers, similarly to that of Strassburg. Two other Benedictine monasteries of Suabia, the first 


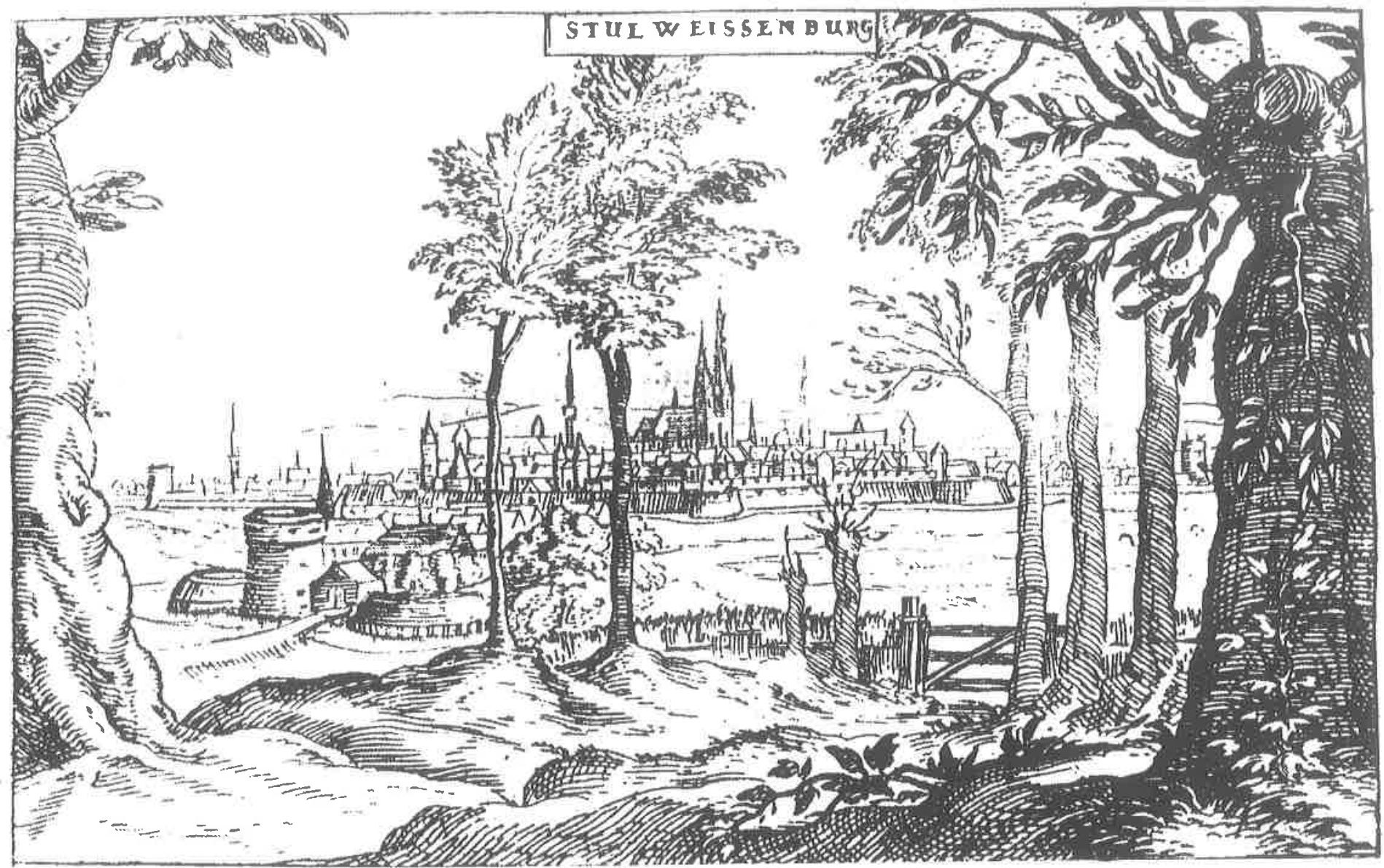

fig. 18. Székesfehérvár, engraving of W. Dillich, 17th century

church of Schaffhausen ${ }^{61}$ (dated between 1050 and 1064) and St Aurelius church at Hirsau ${ }^{62}$ (built in 1059-71) were also built with two western towers. The first monks came to Muri, Schaffhausen and Hirsau from Einsideln. There are arguments for a reconstruction of this church (103139) with a two-tower façade too. ${ }^{63}$ Thus it can be accepted that one of the most important territories in the early history of the two-tower façade was the Suabian region.

The early Hungarian connections with Suabia were not limited to the ecclesiastic sphere. Suabian nobles came to the Hungarian court already during the reign of Duke Géza. They played a leading role in the battle between Saint Stephen and his pagan rival Koppány (c. 997). ${ }^{64}$ Nevertheless, we should not forget about bishop Bruno of Augsburg (1006-29), brother of Queen Gisella. From Augsburg we know a church with two-tower façade, as well (St Stephen, built from 968/9).$^{65}$ Some years later a relative of King Stephen married the Suabian Count Eppo von Nellenburg, father of the founder of the above-mentioned monastery at Schaffhausen. ${ }^{66}$

Even more important could be Hungary's connections with Bavaria at this time. The two-tower façade was known here too. The cathedral of Salzburg rebuilt by archbishop Hartwik (991-1023) had a massive western complex. Although its reconstruction is not evident, most probably it had a two-tower façade. ${ }^{67}$ This kind of arrangement was also used in other Bavarian buildings at that time. The Benedictine monastery of Tegernsee still preserves the remains of the two original western towers of the early 11 th century. ${ }^{68}$ We have sources proving the connections between these centres and
Hungary. King Stephen is mentioned in the necrologies of the abbeys of Tegernsee ${ }^{69}$ and St Peter at Salzburg. ${ }^{70}$

Hence the presence of the two-tower façade in the early Hungarian architecture can be explained by architectural parallels and ecclesiastical and other connections. However, it is possible that Hungary was not an exception in this respect in the region. There is sporadic evidence from Bohemia and Poland that this structure was also known there. It is not clear if the second church at Stará Boleslav, in Bohemia, (consecrated in 1046) can be interpreted with a twotower façade, ${ }^{71}$ and the reconstruction of the Benedictine monastery church at Ostrov (founded before 1000) is similarly uncertain. ${ }^{72}$ The Polish cathedrals of Poznan and Gniezno (from the last quarter of the 10th century and later) are also reconstructed sometimes with two western towers. ${ }^{73}$

Thus, if we have noticed that the various western complexes of the churches of the early 11 th century point to the different origins and unmatured character of the young Hungarian Christianity, we should recognise the first signs of the appearance of an architectural tradition. Western complexes with two towers seem to be more typical for the Hungarian sacral architecture of the period than complexes with westworks, for which it would be hard to find parallels as late as the 11th century. This practice was continued on the buildings of royal Benedictine churches from the late 11 th century (Garamszentbenedek, ${ }^{74}$ founded in 1075 and Somogyvarr, ${ }^{75}$ founded in 1091) and the western towers, sometimes with complicated inner arrangements, later became an essential element of smaller monasteries of 
Hungarian aristocratic families as the church at Lébény (1208-1220 c.) or at Ják (c. 1220-1240s) ${ }^{76}$

On the other hand, we have to emphasise that the early examples certainly differed substantially from the later 'harmonic' two-tower façades. The reconstruction of Schönenwerd is significant not only because of the pres- ence of the towers but because it demonstrates how they were put onto a transversal mass. The typical Ottonian buildings may have appeared for their Romanesque visitors a bit ponderous and complicated; nevertheless, some of the important features of Romanesque architecture go back in a way to just these Ottonian elements.

${ }^{1}$ Mons Sacer 996-1996. Pannonhalma 1000 éve (1000 years of Pannonhalma). Catalogue, Pannonhalma, 1996. Vols. I-III. (with German summaries. For an English summary of the newest results see: G. CSOKA-K. SZOVÁK-I. TAKÁCS, Pannonhalmna. Pictorial Guide to the History and Sights of the Benedictine Abbey, Pannonhalma, 1996).

${ }^{2}$ For the literature of the westwork-problem see F. MÖBIUS, Westwerkstudien, Jena, 1968; and more recently the paper of Miljenko JURKOVIĆ in the present volume. The integration of westworks is mentioned e.g. by C. HEITZ, Architécture et liturgie en France de l'époque carolingienne à l'an Mil, in: Hortus Artium Medievalium I, 1995, pp. 57-73. and G. BANDMANN, Mittelalterliche Architektur als Bedeutungsträger. Berlin, 1951 , p. 208.

${ }^{3}$ We shell see later that this debate focused on the monuments of the Upper Rhine region. Cf. Note 58.

${ }^{4}$ For such a tendency cf. the case of Salzburg cathedral. The archeologist H. Vetters reconstructed the building of archbishop Hartwik with a middle tower and was followed in this respect by R. Wagner-Rieger. In the Nachtragsband of Vorromanische Kirchenbauten the two-tower façade is accepted. Cf. Note 67.

${ }^{5} \mathrm{Cf}$. the case of Székesfehérvár and the literature mentioned there (Note 47).

${ }^{6}$ The most recent editions with commentaries are by GY. GYÖRFFY, Diplomata Hungariae Antiquissima, Vol. I., Budapest, 1992, pp. 26-41; and in the new catalogue (cf. Note 1), G. ÉRSZEGI, Szent István pannonhalmi oklevele (The charter of King Stephen the Saint for Pannonhalma), Vol I., pp. 47-89. For the historiography of the charter: G. THOROCZKAY, Szent István pannonhalmi oklevelének historiográfiaja (The historiography of the charter of King Stephen the Saint for Pannonhalma), ibidem, pp. 90-109.

7 Built by Abbot Uros and consecrated in 1224. For the history of the building of Pannonhalma is still fundamental: F. LEVÁRDY, Pannonhalma épitéstörténete (Building history of Pannonhalma), in: Muvészettörténeti Értesitö8 (1959) pp. 27-43, 101-129, 220-231, ibidem 11 (1962) pp. 1-23. For the most recent results see I. TAKÁCS, Pannonhalma újjáépitése a 13. században (Rebuilding of the abbey church of Pannonhalma in the 13th century), in the mentioned Catalogue (cf. Note 1), pp. 170-236.

${ }^{8}$ For these see: SZ. PAPP, Késő gótikus építkezések Pannonhalmán (Late Gothic building periods in Pannonhalma) in the mentioned Catalogue (cf. Note 1), pp. 237-271

${ }^{9}$ J. SISA, A Könyvtár és a torony építése (The building of the Library and the tower), in the mentioned Catalogue (Note 1), Vol. II, pp. 145-161.

${ }^{10}$ One of them is a part of a series of five drawings of 1787 in Budapest, Magyar Országos Levéltár, T 18 No 4/1-5. The same series with one more drawing can be found in Vienna, Albertina, Architektonkische Zeichnungen, Mappe 91 U 9. Published in Catalogue (cf. Note 1) Vol. II., no. VIII.15., pp. 116-120. Others were made with the help of these drawings by Robert Onderka. in 1859. The drawings were made for Arnold Ipolyi commissioned by the K.K. Komission für Erforschung und Erhaltung der Baudenkmale (Vienna) in 1859. They were made after the rebuilding of the western parts, however, he used earlier drawings and could have got some information from the people living there. Today they are kept in Budapest, Országos Müemlékvédelmi Hivatal, Tervtár, 4254-4256, 4296-4309. Published in: Catalogue (cf. Note 1), Vol. II., no. IX.37., pp. 220-235. and some details in Vol I., pp. 180-181.

${ }^{11}$ It was published on the occasion of an earlier celebration in 1988, on the 950th anniversary of the death of King Stephen the Saint. M. TÓTH, A müvészet Szent István korában (Art under Stephen the Saint), in: Szent István és kora (King St. Stephen and his age), ed. F. Glatz and J. Kardos, Budapest, 1988. pp. 113-132.

${ }^{12}$ Especially the excavations of 1994, led by Csaba László. For these excavations see CS. LÁSZLÓ, Adalékok Pannonhalma középkori történetéhez (Contributions to the medieval history of Pannonhalma), in: Müemlékvédelmi Szemle, 1995/1-2, pp. 89-124. and idem, Régészeti adatok Pannonhalma épitéstörtébetéhez (Archaeological contributions to the building history of Pannonhalma), Catalogue (cf. Note 1), Vol. I. pp. $143-169$.

${ }^{13}$ See Note 10, Catalogue (cf. Note 1) Vol. II. no. VIII.15.d., p. 119, and a better photograph in Vol. I., p. 132.

${ }^{14}$ These observations together with the following ones were published by I. TAKÁCS, op. cit. (Note I4) pp. 176-185. Our interpretation follows the hypothesis of I. Takács.

${ }^{15}$ Drawn by Robert Onderka. See Note 10, Catalogue (cf. Note 1), Vol II., no. IX.37.b. (Inv. no. 4256) with a good photograph in Vol I. p. 181.

${ }^{16}$ E.g. a map from 1728-1734 with the representation of the abbey church, Pannonhalma, Pannonhalmi Bencés Fóapátsági Levéltár, Fasc. 12. n. 51. Catalogue (cf. Note 1) Vol. II., no. VIII.13., pp. 112-113.

${ }^{17}$ The parallels mentioned by I. TAKÁCS in his article (cf. Note 17, pp. 183-184) are the following: cathedral of Basel (early 9th C.), cathedral of Trier, monastery churches of Gernrode, Möllenbeck and Quedlinburg (10th C.) and the cathedrals of Worms and Paderborn (early 11th C.). The cathedral of Bamberg is mentioned by L. CSABA, op. cit. 1996 (Note 12), p. 149.

${ }^{18}$ Vorromanische Kirchenbauten. Katalog der Denkmäler bis zum Ausgang der Ottonen, ed. by F. OSWALD, L. SCHAEFER and H. R. SENNHAUSER, Vol. I-III, München, 1966, 1968, 1971. Vol. I. p. 32, and Vorromanische Kirchenbauten. Katalog der Denkmäler bis zum Ausgang der Ottonen. Nachtragsband, ed. by W. JACOBSEN, L. SCHAEFER and H. R. SENNHAUSER, München, 1991, pp. 42-43.

${ }^{19}$ Monumenta Germaniae Historica, Scriptores, Vol. IV, p. 796 (on the synod of Frankfurt in 1007) and Vol. XVII, p. 636 (Dedicatio ecclesiae S. Petri Babenbergensis). Archbishop Astrik was one of the seven prelates among the 45 participating bishops who consecrated one of the altars.

${ }^{20}$ Vorromanische Kirchenbauten (cf. Note 18) Vol. III., pp. 378-379.

${ }^{21}$ Vorromanische Kirchenbauten, Vol. II. pp. 249-253.

${ }_{22}$ Vorromanische Kirchenbauten, Vol. III., pp. 384-385.

${ }^{23}$ Vorromanische Kirchenbauten, Vol. II., pp. 205-206.

${ }^{24}$ One of the rare parallels is the 12 th century phase of the Benedictine monastery at Pusztaszer. O. TROGMAYER and I. ZOMBORI, Szer monostorától Ópusztaszerig (From the monastery of Szer to Ópusztaszer) Budapest, 1980 and O. TROGMAYER, A pusztaszeri templomrom (The ruined church of 
Pusztaszer), in: Müemlékvédelem 36 (1992), pp. 88-94. Another example, excavated by Zsuzsa Lovag, is a small building of the Benedicine Virgin Mary nunnery at Esztergom-Sziget (Insula Strigoniensis).Zs. LOVAG, Beszámoló az Esztergom-Várszigeti apácakolostor 1979-1983 között végzett feltárásáról (Report of the excavations of the Nunnery at Esztergom-Vársziget between 1979-1983), in: Középkori régészetünk lijabb eredményei és idôszeru feladatai (Newest results and timely tasks of medieval archaeology of Hungary), ed. by I. Fodor and L. Selmeczy, Budapest, 1985, pp. 343-352.

${ }^{25}$ On the other hand, there are arguments that these monasteries were rather small and simple in arrangement. Cf. S. TÓTH, A keszthelyi Balatoni Múzeum középkori kötára (Medieval Lapidarium of the Balaton Museum at Keszthely), in: Zalai Múzelum 2 (1990), pp. 149-187 (remarks on the monastery church of Zalavár on page 148, plan of the monastery on page 175).

${ }^{26} \mathrm{Cf}$. GY. GYÖRFFY, Istuán király és müve (King Stephen and his rule), Budapest, 1977, pp. 177-190; and articles in the mentioned collection: Szent Istuán és kora, 1988 (Note 11).

${ }^{27}$ Cf. E. MAROSI, Die Anfänge der Gotik in Ungarn, Budapest, 1984; idem, Esztergom középkori Szt. Adalbert-székesegyháza - Tiz év múltán (The medieval St Adalbert cathedral of Esztergom — after ten years) in; Limes 7 (1994) no. 3 pp. 13-28.

${ }^{28}$ He led the excavations from 1869 and published the results in: Die Grabungen des Erzbischof von Kalocsa Dr. Ludwig Haynald. Gearbeitet, gezeichnet und erklärt von Dr. Emerich HENSZLMANN, Leipzig, 1873. especially p. 64. The notes and letters of Henszlmann written during the excavation were published by M. KŐHEGYI and K. KOZÁK, Henszlmann Imie kalocsai ásatása (The excavation of I. H. in Kalocsa), in: Archaeologiai Értesítő 102 (1975) pp. 101-116.

${ }^{2 y}$ HENSZLMANN op. cit. 1873 (Note 28) p. 64.

${ }^{30}$ E. FOERK, A kalocsai Szt.-Istuánkori székesegyház érseki sírja (The archbishopric tomb of the cathedral of Kalocsa in the age of King Stephen the Saint) in: Archaeologiai Értesítő 31 (1911), pp. 19-33. and idem, A kalocsai székesegyház (The cathedral of Kalocsa) in: Magyarország Müemlékei (Historical monuments of Hungary), Vol. IV., ed. by Gy. Forster, Budapest, 1915, pp. 43-70.

${ }^{31}$ The excavations, led by Ilona CZEGLÉDY in 1962, were not published. Their results were shortly mentioned by K. KOZÄK, Félkörives szentélyü templomaink a XI. században (Hungarian churches with rounded apses in the 11th century) in: Archaeologiai Értesitö, 93 (1966), p. 54.

${ }^{32} \mathrm{M}$. TÓTH reconstructed the church with two or three towes at the west, cf. op. cit. 1988 (Note 11), p. 117 and note 46.

${ }^{33}$ Scriptores rerum Hungaricarum, ed. by E. SZENTPÉTERY, Vol. II, Budapest, pp.

${ }^{31}$ For the history of Veszprém see: J. GUTHEIL, Az Árpád-kori Veszprém (Veszprém under the Árpád Dynasty), Veszprém, 1977, esp. pp. 58-66. For the building of the cathedral, see: I. ÉRI, M. KELEMEN, L. NÉMETH and I. TORMA, Veszprém megye régészeti topográfiája, A veszprémi járás. Magyarország régészeti topográfiája 2 (Archaeological topography of county Veszprém. District of Veszprém. Archaeological topography of Hungary, Vol. 2), Budapest, 1969, pp. 227-230. The results of the investigations of Sándor Tóth is not yet published fully, however, his results were summerized in his articles on the carvings of the cathedral, cf. Note 37. My thanks are due to Sándor Tóth informing me about his excavations.

${ }^{35}$ For the restoration of the cathedral is fundamental: I. ÁDÁM, A veszprémi székesegyház (Cathedral of Veszprém), Veszprém, 1912.

${ }^{36}$ This is what we can see on the photograph of Mór Erdélyi from the 1900s. Published in: K. JALSOVSZKY and E. TOMSICS, A tegnap világa. Magyarországi városok a századfordulón, (The world of yesterday. Hungarian towns at the turn of the centuries) Budapest, 1992, p. 84.

${ }^{37}$ For the carvings with important notes on the building history see: S. TÓTH, A veszprémi székesegyház középkori kifaragványai I-II (The medieval stone carvings of the cathedral of Veszprém, Part I and II) in: Veszprém Megyei Múzeumok Közleményei l (1963), pp. 115-142. and 19-20 (1993-94) pp. 327-345; idem, A 11. századi magyarországi köornamentika időrendjéhez (To the periodization of ornaments on 1lth centurian Hungarian stone carvings) in: Pannonia regia, Exhibition catalogue, Budapest, Magyar Nemzeti Galéria, 1994, pp. 54-62, and three carvings from 1030-1050, no. I-1, pp. 63-64. ${ }^{3}$ S. PALÁGYI and S. TÓTH, A római és középkori kötár katalógusa, Tihanyi Múzeum (Catalogue of the Roman and medieval lapidary of the Museum of Tihany), Veszprém, 1976., no. 37; S. TÓTH, op. cit. in Pannonia regia (Note 37) p. 55.

${ }^{39}$ A good number of early prints with representations of the castle and its cathedral can be found e.g. in: CS. VERESS G., Várak a Bakonyban (Castles in Mount Bakony), Budapest, 1983.

"10 The chapels between the towers on the north and the south are later additions. For the history of the western facade of the cathedral see: M. TÓTH, A pécsi székesegyház nyugati karzata (The western tribune of the cathedral of Pécs) in: Épités-Épitészettudomány, 15 (1983), pp. 429-455. The next paragraph is based in this hypothesis. For the reconstruction of the early catherdal see especially pp. 448-454.

"The latest fresco cycle of the building can be dated as late as this period. For the Cella Trichora see; F. FÜLEP, A. BACHMAN and Z. PINTÉR: Sopianae-Pécs ókeresztény emlékei (Paleo-Christian monuments of Sopianae-Pécs), Budapest, 1988, esp. pp. 31-35. For the frescos see: M. TÓTH, Árpád-kori falfestészet (Wall painting in Hungary under the Arpad Dynasty), Budapest, 1974, pp. 42-46.

${ }^{12}$ I. HENSZLMANN, A székesfehérvári âsatások eredménye (The results of the excavations in Székesfehérvár), Pest, 1864; idem and L. REISSENBERGER, A nagyszebeniés a székesfehéruári régi templom (The old churches of Nagyszeben and Székesfehérvár), Budapest, 1883; D. DERCSÉNYI, A székesfehérvári királyi bazilika (The royal basilica of Székesfehérvár), Budapest, 1943; A. KRALOVÂNSZKY, Elonzetes jelentés az 1965. évi székesfehérvári feltárásról (Preliminary report of the excavations in 1965 at Székesfehérvár), in: Alba regia VIII-IX (1967-68), pp. 253-262; Régészeti kutatások (Archaeological excavations), ed. by Bánki Zsuzsanna. Székesfehérvár, Bazilika, Romkert. (Excavations of A. KRALOVÁNSZKY, 1970-71) in: Alba Regia XII (1971) pp. 284-285; A. KRALOVÁNSZKY, Székesfehérvár; királyi bazilika I-II (Székesfehérvár, Royal basilica), Budapest, 1988; and several important notes in M. TÓTH, op. cit. 1988 (Note 11).

${ }^{13}$ Cf. J. DEÉR, Aachen und die Herrsschersitze der Arpaden, in: Mitteilungen des Instituts für österreichische Geschichtsforschung, 79 (1971), pp. 5-31.; L. MEZEY, Székesfehérvár egyházi intézményei a középkorban (The ecclesiastical institutions of Székesfehérvár in the Middle Ages), in: Székesfehérvár évszázadai, Vol. II, ed. by A. Kralovánszky, Székesfehérvár, 1972, pp. 23-30.

${ }^{1}$ É. KOVÁCS, Casula Sancti Stephani regis, in: Acta Historiae Artium Academiae Scientiarum Hungaricae, 5 (1958) pp. 181-221; and idem, Iconismus casulae Sancti Stephani regis. Vázlat (Outline), in: Szent István és kora, op.cit. (Note 11), pp. 133-144.

${ }^{15} \mathrm{Cf}$. H. KOLLER, A székesfehérvári királyi trónus kérdése (The problem of the royal throne at Székesfehérvár), in: Székesfehérvár évszázadai, Vol. II, ed. by A. Kralovánszky, Székesfehérvár, 1972, pp. 7-20. Cf. M. TÓTH., op. cit. 1988 (Note 11), p. 118.

${ }^{16} \mathrm{Cf}$. Note 42. Special thanks go to Melinda Tóth for information on the recent excavation as well as for her continuos help and encouragement during my work on this subject.

${ }^{17}$ E.g. E. MAROSI in his chapter on Romanesque art in: A müvészet története Magyarországon (The History of Art in Hungary), ed. by N. Aradi, Budapest, 1983, p. 16. This westwork-theory was fully developed by M. TÓTH, op. cit. (Note 11), pp. 116-119.

${ }^{48}$ For the reduction of the 'Vollwestwerk' see: C. HEITZ, Recherches sur les rapports entre architecture et liturgie à l'époque carolingienne. Paris, 1963, pp. 19-61.

${ }^{19}$ DERCSÉNYI, op. cit. (Note 42) p. 28. Cf. J. BALOGH, A müvészet Mátyás király udvarában (Art in the court of King Matthias), Budapest, 1966, Vol. II, esp. engraving of Wilhem Dillich, 1600 (fig. 294), and a German drawing from 1601 with the inscription "Die ander Kirchen mit den Zwayen Thürmen" 
(fig. 296). An important exception is a representation of the siege of 1601 by F. Montreux (see: CS. VERESS D. and GY. SIKLOSI, Székesfehérvár, a királyok városa (Székesfehérvár, the Kings' Town), Budapest, 1990, p. 127. )

${ }^{50}$ Cf. Note 26 and L. J. CSÓKA, A magyarok és a kereszténység Géza fejedelem korában (Hungarians and Christianity in the time of Duke Géza), in: Ernlékkönyv Szent Istuán király halálának kilencszázadik évfordulóján (Essays presented on the occasion of the 900th anniversary of death of St Stephen), ed. by J. Serédy, Budapest, 1938, Vol. I, 267-29l. GYÖRFFY op. cit. 1977 (Note 26), pp. 67-81 and 177-190.

${ }^{5]}$ Monumenta Germaniae Historica, Scriptores, Vol. IV, pp. 525-542 (Othloni vita S. Wolfkangi episcopi, esp. c. 13, pp. 530-1) and 546-574 (Ex Arnoldi libris de S. Emmerammi, esp. Liber II, c. 1, p. 556). Cf. GYÖRFFY op. cit. 1977 (Note 26), p. 72.

52 Monumenta Germaniae Historica, Epistolae selectae, Vol. III, pp. 100-101; A. F. GOMBOS, Catalogus Fontium Historiae Hungaricae, Budapest, 1937-38, Vol. III, no. 4126, p. 1776. Cf. GYÖRFFY op. cit. 1977 (Note 26), pp. 68-76

${ }_{51}$ Codex Diplomaticus Hungariac, ed. G. FEJÉR, Vol I, Buda, 1829, pp. 123-124, 158-161, 252-257, 260-266, 266-270, 258-260; and R. MARSINA, Codex diplomaticus et epistolaris Slovaciae, Vol. I, Bratislava, 1971, no. 4, pp. 5-6; no.42, pp. 39-40; no 44, pp. 41-43; no. 45, pp. 44-46; no. 46, p. 46. Cf. GYÖRFFY op. cit. 1977, p. 77.

${ }^{54}$ Monumenta Germaniae Historica, Scriptores, Vol. IV, pp. 581-595 (Vita antiquor auctore Iohanne Canapario) and 596-612 (Vita secunda auctore Brunone archiepiscopo); cf. GYÖRFFY op. cit. 1977, pp. 78-80.

${ }^{55}$ E. HERMANN, A katolikus egyház története Magyarországon 1914-ig (History of the Catholic Church in Hungary until 1914), München, 1973, p. 30. ${ }^{56}$ Monumenta Germaniae Historica, Scriptores Vol. IV, p. 547 (see Note 51).

${ }^{57}$ J. TÖRÖK, A középkori magyarországi liturgia története (History of medieval Hungarian liturgy), in: Kódexek a középkori Magyarországon (Codices in medieval Hungary). Exhibition catalogue, Budapest, Országos Széchényi Könyvtár, 1986, pp. 49-66, esp. p. 50.

${ }^{58} \mathrm{H}$. SCHAEFER, The Origin of the Two-Tower Facade in Romanesque Architecture, in: The Art Bulletin, 1945, pp. 85- 108. and H. REINHARDT, Das erste Münster zu Schaffhausen und die Frage der Doppelturmfassade am Oberrhein, in: Anzeiger für Schweizerische Altertumskunde37(1935) pp. 241-257; idem, La cathédrale de Strasbourg, Paris, 1972, esp. pp. 41-45.

${ }^{59}$ Founded in the second half of the 7th century, and refounded a few decades later. G. LOERTSCHER, Die romanische Stiftskirche von Schönenwerd, Basel, 1952; idem, Stiftskirche Schönenwerd SO (Schweizerische Kunstführer 434), Bern, 1988.

${ }^{60}$ G. GERMANN, Die Kunstdenkmäler des Kantons Aargau Vol. V, Der Bezirk Muri, Basel, 1967; P. FELDER, Kloster Muri (Schweizerische Kunstführer), Basel, 1972

${ }^{61}$ W. DRACK, Zur Baugeschichte des Münsters zu Schaffhausen, in: Zeitschrift für Schweizerische Archäologie und Kunstgeschichte 14 (1953), pp. 1-23 and 17 (1957), pp. 14-45; R. FRAUENFELDER, Die Kunstdenkmäler des Kantons Schaffhausen, Basel, Vol. I (1951) pp. 74-75, Vol. III (1960) pp. 315-322.; W. U. GUYAN, Das Salvator-Kloster zu Schaffhausen, in: Zeitschrift für Schweizerische Archäologie und Kunstgeschichte 36 (1979), pp. 151-204; H. R. MEIER, Suisse romane, Zodiaque, 1996 (3e edition entièrement nouvelle), pp. 283-292.

${ }^{62}$ W. HOFFMANN, Hirsau und die "Hirsauer Bauschule", München, 1950, pp. 12-15; M. PUTZE, Zu den Bauten des Aurelienklosters, in: Hirsau: St. Peter und Paul 1091-1991. Hrsg. v. Landesdenkmalamt Baden-Württemberg, Archäologische Denkmalpflege, Stuttgart, 1991, pp. 11-62.

${ }^{63}$ Vorromanische Kirchenbauten, Nachtragsband (Note 18), pp. 111-112.

${ }^{61}$ Gy. GYÖRFFY, op. cit. 1977 (Note 26), pp. 82-83, 108, 116-117, 509; idem, Krónikáink és a magyar östörténet. Régi kérdések- új válaszok (The chronics and the early history of Hungarians. Old questions — new anwsers), Budapest, 1993, p. 185. The most important source is the charter of King Stephen (see Note 6).

${ }^{65}$ Vorromanische Kirchenbauten, Nachtragsband, pp. 37-38.

${ }^{66}$ The tradition identified her with one of the king's daughters, cf. Acta Sanctorum Boll. Aprilis, Tom. I. p. 667. This identification is usually refused (as M. WERTNER, AzÁrpádok családi története (Family history of the Arpad Dynasty), Nagy-Becskerek, 1892, p. 52-54) but it can point to a real connection in a way.

${ }^{67}$ Vorromanische Kirchenbauten, Vol. III, pp. 292-294, Nachtragsband pp. 358-359; with different reconstruction: R. WAGNER-RIEGER, Mittelalterliche Architectur in Österreich, St. Pölten-Wien, 1988, pp. 34-35.

${ }^{68}$ Vorromanische Kirchenbauten, Vol. III, pp. 330-331.

${ }^{69}$ Necrologium Tegemseense, see: GOMBOS op. cit. 1937-38 (Note 52), Vol. II p. 1677, no. 3953; Monumenta Germaniae Historica, Necrologia Germaniae, Vol. III, p. 149.

${ }^{70}$ Monumenta necrologica monasterii s. Petri Salisburgensis, see: GOMBOS op.cit. 1937-38 (Note 52), Vol. II, p. 1661, no. 3821; cf. Monumenta Germaniae Historica, Necrologia Germaniae, Vol. II., p. 46. The archbishopric and the St Peter monastery of Salzburg were in a close connection and the archbishops were abbots of St. Peter until 987. Cf. Festschrift St. Peter zu Salzburg 582-1982, Salzburg, 1982.

${ }^{7}$ As Merhautová, see: A. MERHAUTOVÁ and D. TRESTIK, Románské uměnív Čechách a na Moravě (Romanesque art in Bohemia and Moravia), Praha, 1983, p. 70; the early presence of the towers are debated by E. BACHMANN, Romanik in Böhmen, München, 1977, pp. 71-72.

${ }^{72}$ Reconstructed with two towers by BACHMANN, op. cit., pp. 77-78; the towers are dated to the 12th C. by A. MERHAUTOVA, op. cit. p. 143.

${ }^{73}$ Sztuka Polska przedromańska i romaniska do schylku XIII wieku (Pre-Romanesque and Romanesque Polish art until the end of 13 th C.), ed. by M. WALICKI, Warszawa, 1971, pp. 81-85, 100-103; Z. ŚWIECHOWSKI, Budownictwo romańskie w Polsce (Romanesque monuments in Poland), WroclawWarszawa-Kraków, 1963, pp. 43-48 and 208-213; idem, Romanesque Art in Poland, Warsaw, 1983, pp. 241-242; Vorromanische Kirchenbauten, Nachtragsband (Note 18), p. 148.

${ }^{73}$ N. KNAUZ, A Garan-melletti Szent-Benedeki apátság, ('The abbey of Szent-Benedek on the Garam river), Budapest, 1890, p. 34; V. MENCL, Stredoveká architektúra na Slovensku (Medieval architecture in Slovakia), Praha-Prešov, 1937, pp. 77 and 100-103. The presence of the western tribune is accepted by M. TÓTH op. cit. 1983 (Note 40), p. 446, note 34.

${ }^{7} \mathrm{~K}$. BAKAY, Szent László somogyuári apátsága és a somogyi ispáni vár (The abbey of King Ladislas the Saint in Somogyvár and the county castle of Somogy), in: Müemlékvédelem 36 (1992), pp. 107-110 (with earlier literature). A complex structure was reconstructed at the west by M. TÓTH, op. cit. 1983 (Note 40), note 34, whose fundamental contributions were yet published only partially: A somogyvári bencés apátság és temploma az Ârpádkorban (The church of the Benedictine abbey of Somogyvár under the Árpád Dynasty), in: Szent László és Somogyvár (St. Ladislas and Somogyvár), ed. by K. Magyar, Kaposvár, 1992. pp. 221-250.

${ }^{76}$ For the spatial organization of the 13 th centurian abbey churches in Hungary see from the earlier literature: G. ENTZ, Westemporen in der ungarischen Romanik, in: Acta Historiae Artium Academiae Scientiarum Hungaricae 6 (1959), pp. 1-19; and idem, Zur Frage der Westemporen in der mittelalterlichen Kirchenarchitektur Ungarns, in: Funktion und Gestalt, ed. by F. Möbius and E. Schubert, Weimar, 1984, pp. 240-245. More recently see: B. ZS. SZAKÁCS, Zur Typologie der Westemporen, in: Mitteleuropa. Kunst, Regionen, Beziehungen, Hrsg. v. Stefan Oriško, Bratislava, 1993, pp. 4-13; and idem, Ambiva- 
lent Spaces in Western Complexes of Medieval Hungarian Conventual Churches, in: Czas i przestrzeń w kulturze średniowiecza. Materialy XIV seminarium mediewistycznego (Space and time in medieval culture. Materials of the 14th medievist seminar), Poznan 1994, pp. 30-32. On Ják recently: A. MEZEYDEBRECZENI and E. SZENTESI, Neue Forschungen zur Abteikirche von Ják, in: Kunstchronik, 44 (1991), pp. 575-584. and T. v. BOGYAY, Bamberg und Ják im Licht neuer Forschungen, in: Künstlerischer Austausch: Akten des XXVIII. Internationalen Kongresses für Kunstgeschichte, Hrsg. v. T. W. Gaehtgens, Berlin, 1993, Vol. 2, pp. 81-88.

\section{WESTWERK U MADARSKOJ U PRVOJ POLOVICI XI. ST'OLJEĆA}

Katedrale, priorati i samostani sagrađeni u vremenu organiziranja crkve za kraljevanja Svetog Stjepana (9971038.) uglavnom su tijekom stoljeća nestali. Ipak, uz pomoć iskopavanja, pisanih izvora i starijih prikaza, moguće je djelomično rekonstruirati njihovu prostornu organizaciju.

Jedna od najvažnijih kraljevih fondacija, priorat $\mathrm{u}$ Székesfehérváru imao je na zapadnoj strani bočnih brodova par tornjeva, a glavni brod bio je lukovima rastvoren prema prostranom zapadnom sklopu. Ta kraljevska crkva, obdarena brojnim privilegijama, imala je i neke posebne funkcije. U njoj je pokopan kralj Stjepan, bila je to krunidbena crkva mađarskih kraljeva, a ondje je čuvana i kraljevska kruna s moćima. Te funkcije moguće je djelomično vezivati uz zapadni sklop.

Prve katedrale podignute su također s impozantnim zapadnim sklopovima. Najstarija crkva u Kalocsi imala je na zapadu dva tornja kojima su kasnije pridodana još dva. Katedrala 12. stoljeća u Pečuhu imala je jedinstveno zapadno pročelje koje je moguće objasniti samo rekonstrukcijom izgleda prethodne građevine s transverzalnim volumenom (transept) s lukovima.

Najstarije samostanske crkve, osnovane oko 1000. godine, manje su poznate. Nedavna istraživanja u Pannon- halmi pokazala su da je crkva tog najstarijeg i najznačajnijeg mađarskog benediktinskog samostana imala zapadnu apsidu s kriptom, a možda i tornjićima. Nedvojbeno je da su najranije građevine nove mađarske crkve imale složene zapadne dijelove koji su se razlikovali od crkve do crkve. Te razlike moguće je usporediti i s ranom fazom mađarske liturgije koja je imala nekoliko izvorišta; od St. Gallena i Reichenaua do Mainza, od Magdeburga do Passaua i Salzburga. No i Gornje Porajnje bilo je značajno zbog svoje uloge u razvoju pročelja s parom tornjeva (možda Strassburg, Schönenwerd, Muri, itd.). Takav tlocrt imala je Hartwickova katedrala u Salzburgu (991-1023). Moguće je da zapadne tornjeve u Székesfehérváru i Kalocsi također treba interpretirati na taj način. To ne bi bili jedini primjeri u istočnom dijelu srednje Europe (usp. Gniezno i Poznan u Poljskoj ili Ostrov i Stara Boleslav u Češkoj), što pokazuje da ovaj prostor ne bi trebalo isključiti iz najranije povijesti pročelja s parom tornjeva. Usprkos svemu, očito je da se radi o građevinama prilično različitim od klasičnih primjera ovog tipa koji se u Mađarskoj javlja tek u kasnom XI. stoljeću (Dombó, Garamszentbenedek, Somogyvár) zajedno sa stilskim novinama romaničkog razdoblja. 
